\title{
РАЗВИТИЯ ТЕОРИИ СТРОЕНИЯ АССОРТИМЕНТОВ ТКАНИ
}

\section{Яминзода 3.А.}

к.Т.Н, доцент

Технологический университет Таджикистана

Аннотация: На протяжении последних лет мода неоднократно обращала внимание на ткани традиционных структур (креп, крепдешин, габардин, трико, драп и др.), предоставляя неограниченные возможности использования их для различных видов одежды. Четко выраженный характер рисунка, его современные мотивы в сочетании с высокими эксплуатационными характеристиками и комфортность ставят их в ряд наиболее востребованных тканей у населения. Очень популярны и новые ткани с использованием кашемира, альпака, такого сырья, как пух монгольских коз и шерсть ангорских коз.

В основу развития ассортимента бытовых тканей положено их соответствие требованиям современного потребителя, поэтому все большее значение приобретают качество и утилитарность, разнообразие фактур и художественно-колористическое оформление.

Ключевые слова: ткань, дизайн, одежда, хлопковый, шелк, шерсть, лён, переплетения.

\section{DEVELOPMENT OF THE THEORY OF STRUCTURE OF FABRIC ASSORTMENTS}

Yaminzoda Z.A. candidate of technical sciences, associate professor Technological University of Tajikistan

\footnotetext{
Abstract: Over the past years, fashion has repeatedly drawn attention to the fabrics of traditional structures (crepe, crepe de chine, gabardine, leotards, drapes, etc.), providing unlimited opportunities for their use for various types of clothing. The clearly expressed character of the pattern, its modern motives, combined with high performance and comfort, put them among the most popular fabrics among the population. New fabrics using cashmere, alpaca, raw materials such as Mongolian goat down and Angora goat wool are also very popular.
} 
The development of the assortment of household fabrics is based on their compliance with the requirements of the modern consumer, therefore, quality and utility, a variety of textures and artistic and coloristic design are becoming increasingly important.

Keywords: fabric, design, clothing, cotton, silk, wool, linen, weaves.

Bce современные ткани делятся по назначению на бытовые и технические. Бытовые ткани используют для изготовления одежды и бытовых швейных изделий. Эти ткани вырабатывают почти из всех видов волокон и нитей. В зависимости от вида волокнистого состава их подразделяют на хлопчатобумажные, льняные, шерстяные и шелковые (из натурального шелка и химических нитей). Выделяют ткани:

- однородные - из одного вида волокон или нитей либо с примесью не более $10 \%$ других видов;

- смешанные - из нитей, полученных из нескольких видов волокон;

- неоднородные - в которых чередуются различные виды нитей.

По назначению бытовые ткани делят на бельевые, платьевые, костюмные, пальтовые, мебельно-декоративные и др.;

- по структуре пряжи - на ткани из кардной, гребенной и аппаратной пряжи;

- по характеру отделки - на суровые, отбеленные, гладкокрашеные, набивные, пестротканые, меланжевые, ворсовые;

- по виду дополнительной обработки - на аппретированные, мерсеризованные, тисненые, гофрированные, несминаемые, малоусадочные и др.;

- по переплетению - на простые, мелкоузорчатые, сложные, крупноузорчатые.

Все виды тканей, отличающиеся друг от друга хотя бы одним показателем заправочных данных (толщина нитей, число их на единицу длины и ширины, переплетение и т. д.), обозначаются условными номерами артикулами.

Ткани, длительное время вырабатываемые без изменений, пользующиеся постоянным спросом у населения, называют классическими. Они имеют традиционные названия - ситец, бязь, кисея, маркизет, крепдешин, бархат, сукно, кашемир, драп и многие другие. Их обновление связано с требованиями моды и выражается обычно в обращении и частичном 
изменении классических структур в новом художественно-колористическом решении.

Комбинируя смесовые составы, различные виды отделки и приемы оформления, получают контрастные материалы: плотные и в то же время ажурные или тисненые и мягкие подворсованные.

Важными из общих требований, предъявляемых к современной одежде, являются:

- достаточно легкая растяжимость тканей и полотен, обеспечивающая свободу движения в относительно больших диапазонах изменения размеров тела человека;

- высокая степень восстановления первоначальных размеров изделий после прекращения действия деформирующего усилия.

В связи с этим большую актуальность и высокий спрос во всем мире приобретает сегодня одежда с использованием нитей, обладающих высокой растяжимостью.

Ведущие фирмы мира активно используют ткани и трикотажные полотна «стретч» («стрэйч»), которые за счет применения полиуретановых нитей (ПУ) - лайкры (фирма «Дюпон», США), спандекса («Волжский завод», Россия), дорластана (фирма «Байер», Германия) создают огромные возможности для моделирования и изготовления одежды высокого качества, комфортной и удобной в эксплуатации, спортивной, авангардной молодежной, повседневноделовой и вечерней.

Технические ткани выпускаются всеми отраслями текстильной промышленности и используются для изготовления деталей машин, приводных ремней, фильтров, конвейерных лент, тентовых сооружений, для технических изделий в дорожном строительстве, сельском хозяйстве и др.

\section{Хлопчатобумажные ткани}

В ассортименте тканей, выпускаемых хлопчатобумажной промышленностью, насчитывается более 1000 артикулов. При этом нужно учитывать, что со временем часть тканей снимается с производства, осваиваются их новые виды. Есть ткани, которые выпускаются в течение длительного времени. Они мало подвержены влиянию моды, предназначены для массового потребителя, вырабатываются в больших количествах. К ним относятся ситцы, бязи, сатины, полотенечные ткани и другие. Эти ткани 
прошли проверку в условиях длительной эксплуатации, они гигиеничны, воздухопроницаемы, гигроскопичны, за ними легко ухаживать.

Хлопчатобумажные ткани, в зависимости от назначения, художественно-колористического оформления и способа изготовления подразделяются на 16 основных групп: ситцевая группа; бязевая группа; бельевая группа (бязевая, миткалевая и специальная подгруппы); сатиновая группа; платьевая группа (демисезонная, летняя и зимняя подгруппы, ткани из смеси хлопка и химических волокон); одежная группа (подгруппа гладкокрашеных тканей, специальная, подгруппа меланжевых и пестротканых тканей зимняя подгруппа); подкладочная группа; ворсовая группа; платочная группа; полотенечная группа; группа суровых тканей; мебельно-тиковая группа; одеяльная группа; группа тарных и упаковочных тканей; группа марлевых тканей; группа технических тканей.

Деление ассортимента выпускаемых тканей на группы и подгруппы производится, с одной стороны, по назначению (бельевая, платьевая, подкладочная, полотенечная, платочная и др.), с другой - по особенностям структуры (сатиновая группа), а также по признакам свойств, которые ткани приобретают в результате технологических процессов производства.

В ряде подгрупп учитывается сезонность назначения (демисезонная, летняя и зимняя подгруппы платьевой группы).

Хлопчатобумажные ткани вырабатываются из гребенной, кардной и аппаратной пряжи и пряжи пневмомеханического прядения различных структур (однониточной, крученой, фасонной) различной линейной плотности, которая колеблется в очень широком диапазоне - от 5,88 до 263,2 текс. Помимо хлопчатобумажной применяют смешанную пряжу (хлопкольняная, хлопковискозная, хлопкополинозная, хлопкосиблоновая, хлопколавсановая) и химические комплексные нити (вискозные, ацетатные, капроновые).

При выработке тканей используются практически все виды ткацких переплетений. Поверхностная плотность тканей зависит от их назначения и может быть от 36 до 815 г/м²; ширина тканей 75-220 см. Художественноколористическое оформление тканей очень разнообразно: гладкокрашеные, печатные, пестротканые, меланжевые, отбеленные (с разной степенью белизны), суровые. Широко используются специальные виды отделок стойкое тиснение, лощение, гофрирование, несмываемые аппреты, водоотталкивающие пропитки, малоусадочная и малосминаемая отделки и др. 
В хлопковых тканях акцент ставится на создание визуальных эффектов. Благодаря специальной обработке ткани облагораживаются и приобретают черты индивидуальности. Ткани из хлопка в зависимости от отделки могут быть пластичными и воздушными или жесткими, бумагоподобными, но в основном легкими и тонкими.

Хлопчатобумажные ткани обладают хорошей износостойкостью, высокими показателями гигиенических свойств, хорошо переносят многократные стирки и тепловые обработки, светоустойчивы. Поэтому они имеют разностороннее применение, пользуются устойчивым спросом.

Большее место в ассортименте занимают классические или традиционные хлопчатобумажные ткани, такие как ситцы, бязи, батисты, сатины, маркизет, кисея, шотландка, вельветы и др.

Новые ткани вырабатывают с использованием химических волокон и нитей, которые придают хлопчатобумажным тканям определенные свойства и своеобразное туше. Так, вискозные волокна придают хлопчатобумажным тканям мягкость, шелковистость, повышенную драпируемость, при этом хорошие гигиенические свойства тканей сохраняются, хотя несколько снижается их устойчивость к трению и стиркам. Хлопок в смеске с шерстью приобретает эластичность. Высокомодульное волокно сиблон (его обычно используют в количестве 33\% для платьевых, сорочечных и бельевых тканей) сохраняет все положительные свойства хлопчатобумажных тканей и, кроме того, ткани с сиблоном приобретают шелковистость и мягкость, лучше окрашиваются. При вложении лавсана хлопчатобумажная ткань меньше сминается и усаживается, однако становится жестче, приобретает «колючее» туше, показатели гигиенических свойств снижаются. Так, при содержании волокна лавсан в хлопчатобумажной ткани (типа бязи) в количестве 33,50 и 67 \% паропроницаемость ткани снижается соответственно на 15,4, 24 и $33 \%$. Ткани из смески хлопка с нейлоном - водостойкие, с защитными покрытиями из силикона, каучука, пропитанные воском или специальными составами дают скользящие «жирные» поверхности.

По назначению хлопчатобумажные ткани можно разделить на бельевые, сорочечные, платьевые, одежно-костюмные, платочные, одеяльные, мебельнодекоративные и технические.

Cuтиы - классические хлопчатобумажные ткани полотняного переплетения, вырабатываемые из кардной пряжи и пряжи пневмомеханического прядения средней толщины (18,5 и 20 текс по 
основе; 15,4 и 20 текс по утку) с поверхностной плотностью от 92 до 103

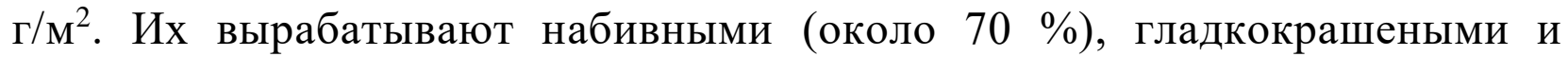
отбеленными, мягкой и жесткой отделки. Ситцы отличаются высокими потребительскими свойствами. Они красивы, легки, достаточно прочны, имеют высокую воздухопроницаемость. Кроме основного назначения для женских и детских летних платьев, ситцы используют и для белья, мужских и детских сорочек, халатов, наволочек и в качестве декоративных тканей. В процессе технологической переработки затруднений не вызывают.

Бязи (кроме бельевых) - традиционные ткани полотняного переплетения, вырабатываемые из кардной и пневмомеханической пряжи, с поверхностной плотностью 140-160 г/м². Отделка бязей обычно жесткая, поэтому они кажутся более плотными. Платьевые бязи вырабатывают с малосминаемой и противоусадочной отделкой. Рисунки набивных бязей различны в зависимости от их назначения - платьевые, сорочечные, декоративные. Гладкокрашеные бязи применят главным образом для рабочей одежды, спецодежды, подкладки и прокладки. Основные технологические свойства и режимы обработки аналогичны ситцам.

БЕЛЬЕВЫЕ ТКАНИ - подразделяются на бязи, миткали и специальные. Они предназначены для нательного (нижнего), постельного, столового белья.

Миткали - ткани полотняного переплетения из кардной пряжи средней линейной плотности (18,5-15,4 текс); по структуре аналогичны ситцам; вырабатываются отбеленными и светлоокрашенными. В зависимости от отделки имеют разные названия:

муслин - миткаль с мягкой отделкой;

миткаль бельевой - миткаль с полужесткой отделкой;

мадаполам - миткаль с жесткой отделкой.

Специальные бельевые ткани - это гринсбон и тик-ластик.

Гринсбон - вырабатывается переплетением «ломаная саржа», тик-ластик - атласным. Для их выработки применяют более толстую пряжу - 25 текс по основе и 42,8 текс по утку. Ткани имеют повышенную плотность и относятся к более тяжелым бельевым тканям (165-197 г/м²). Они в основном вырабатываются отбеленными, обладают высокой прочностью, эластичностью. При настилании не растягиваются, не перекрашиваются, при стачивании могут прорубаться. Гринсбон - это прочный хлопчатобумажный материал, получаемый путем саржевого плетения. При этом ткань 
дополняется ткацким узором «елочка». Предполагается, что материал впервые появился в Англии, поскольку слово английские корни, а клетчатый узор самый популярный у англичан.

Camuны - классические гладкие блестящие ткани, легкие или средней массы, с плотным гладким лицевым застилом уточных нитей (у сатинов) или основных нитей (у атлас). Их вырабатывают из кардной или гребенной пряжи пятиниточным сатиновым переплетением. Для некоторых сатинов используют хлопкосиблоновую пряжу. В зависимости от применяемой пряжи сатины подразделяют на кардные, гребенные (тонкие) и полугребенные (полутонкие). Полугребенные сатины вырабатывают из кардной пряжи в основе и гребенной пряжи в утке. Для отдельных артикулов кардных сатинов используют пневмомеханическую пряжу. Все тонкие и полутонкие сатины, а также некоторые кардные мерсеризуют. Их выпускают гладкокрашеными, набивными и отбеленными. Сатины обычно имеют мягкую отделку, некоторые сатины подвергают лощению, стойкому тиснению и серебристошелковистой отделке.

Подгруппа летних тканей характеризуется легкостью, невысокой плотностью и хорошей проницаемостью. Большая часть этих тканей вырабатывается из тонкой гребенной пряжи 14,3-7,5 текс, а также пряжи

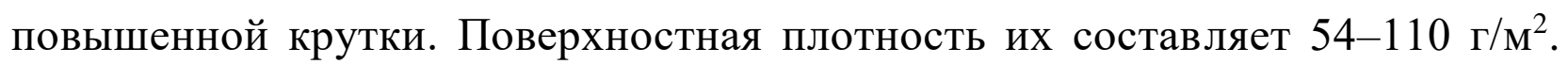
Для увеличения гигроскопичности и придания шелковистого блеска значительную часть тканей мерсеризуют. Выпускают ткани набивными, гладкокрашеными и отбеленными. Большое место в ассортименте летних тканей занимают классические ткани полотняного переплетения - батист, маркизет, майя, вуаль, вольта и мелкоузорчатых переплетений - канифас, кисея и др.

Батист, майя, вольта вырабатываются из гребенной некрученой пряжи. Они обладают мягким туше и шелковистым блеском.

Маркизет - высококачественная полупрозрачная платьевая ткань с муаровым эффектом - вырабатывается из очень тонкой гребенной крученой пряжи. Благодаря применению крученой пряжи ткань обладает повышенной упругостью и жестковатым туше.

Вуаль - ткань типа утолщенного маркизета; характеризуется повышенной упругостью, некоторой жесткостью и сыпучестью.

Канифас - ткань из кардной пряжи средней толщины, с рельефным тканым рисунком на поверхности. 
Подгруппа платьевых тканей с комплексными нитями вырабатывается из хлопчатобумажной пряжи в основе и некрученых вискозных или ацетатных нитей в утке, образующих на лицевой стороне блестящий эффект. Их вырабатывают полотняными, различными мелкоузорчатыми или жаккардовыми переплетениями. Ткани могут быть отбеленными, гладкокрашеными или с печатным рисунком, с поверхностной плотностью 100-250 г/м². Используются для женских и детских летних платьев, блузок, мужских сорочек. В тканях с длинным уточным перекрытием при носке искусственные нити дают затяжки, образуют пилли, что значительно портит внешний вид одежды.

Подгруппа демисезонных платьевых тканей характеризуется сравнительно большей плотностью, средней поверхностной плотностью (106$\left.210 \Gamma / \mathrm{M}^{2}\right)$ и разнообразной структурой. Для этих тканей характерно большое разнообразие пряжи по толщине и строению: кардная, гребенная, пневмомеханического способа прядения 83-5,8 текс, однониточная, крученая и фасонная. Ткани вырабатывают полотняным, саржевым, мелкоузорчатым и жаккардовым переплетениями. Они имеют меньшую воздухопроницаемость и поэтому лучшие теплозащитные свойства. Некоторые из них имитируют шерстяные ткани. Традиционными в подгруппе являются шерстянка, кашемир, шотландка и др., которые обновляются за счет новых модных тканых и набивных рисунков.

Kpen платьевой вырабатывают из крученой гребенной пряжи креповым переплетением с мелкозернистой шероховатой поверхностью, с приятным шелковистым туше.

Около $60 \%$ демисезонных тканей составляют ткани сорочечные. Среди них большое место занимают традиционные рубчиковые (ложнорепсовые) ткани - поплин, репс, тафта, пике и др.

Поплин вырабатывают из тонкой крученой гребенной пряжи по основе и более толстой пряжи по утку. Это плотная ткань полотняного переплетения с заметным поперечным рубчиком, образованным сочетанием в основе и в утке пряжи различной линейной плотности. Поплин бывает отбеленным, гладкокрашеным, с печатным рисунком. Поверхностная плотность $105 \Gamma / \mathrm{M}^{2}$.

Тафта по структуре аналогична поплину, но имеет большую плотность по основе, вследствие чего эта ткань более тяжелая. 
Пике - классическая плотная ткань из гребенной пряжи, отбеленная, гладкокрашеная или с печатным рисунком, с выпуклым продольным рубчиком, образованным сложным переплетением. В новом ассортименте пике вырабатывается крупноузорчатыми сложными переплетениями с разнообразными по форме жаккардовыми рисунками. Применяется для женских и детских изделий. Поверхностная плотность 136-167 г/ $\mathrm{m}^{2}$.

Гарус - плотная, сравнительно тяжелая ткань полотняного переплетения, выработанная из кардной пряжи в два сложения, низкой линейной плотности. Ткань грубоватая, имеет печатный рисунок, имитирующий пестроткань. Используется для детских костюмчиков, обладает повышенной осыпаемостью. Поверхностная плотность 172 г/м².

Перкаль - тонкая, плотная ткань полотняного переплетения. Ткань отделанная используется для пошива женских летних платьев. Выпускается чисто хлопковой (100\%) с применением полиэстра (50/50), поверхностная плотность 65-122 г/ $\mathrm{M}^{2}$, ширина от 90 до $240 \mathrm{~cm}$.

Подгруппа зимних платьевых тканей включает толстые ткани с односторонним или двухсторонним ворсовым начесом, выработанные в основе из кардной пряжи средней линейной плотности, а в утке - из толстой пушистой аппаратной пряжи, подвергающейся в отделке ворсованию. Ткани широко используются для изготовления демисезонных и зимних изделий детского ассортимента, женских домашних платьев и халатов, теплых мужских сорочек. В подгруппу входят традиционные фланель, бумазея, байка. Они вырабатываются гладкокрашеными и печатными.

Фланель вырабатывается полотняным или саржевым переплетением, имеет двухсторонний начес. Это наиболее тонкая, мягкая и легкая ткань в подгруппе. Поверхностная плотность 164 г/м². Фланели выпускаются хлопчатобумажные, хлопковискозные $(20 \%$ вискозного волокна) и хлопкосиблоновые (до 33\% волокон сиблона).

Бумазея вырабатывается саржевым, полотняным или мелкоузорчатым переплетением с односторонним начесом (с изнанки или лицевой стороны); иногда используется вискозный уток, образующий на лицевой стороне блестящий шелковистый направленный ворс. Бумазея несколько толще и тяжелее, чем фланель, ее поверхностная плотность 180 г/м².

Байка вырабатывается двухлицевым переплетением, имеет двухсторонней начес. Это наиболее толстая и тяжелая ткань зимнего ассортимента, имеющая поверхностную плотность 335-460 г/м². 
Одежные ткани подразделяются на подгруппы: гладкокрашеные (диагональ, молескин, репс и др.), меланжево-пестротканые (диагональ, коверкот, джинсовые ткани), специальные, зимние (сукно, вельветон) и т. д. В этот ассортимент входят определенные, уже классические ткани со стабильными структурой и свойствами, они выпускаются на протяжении многих лет. Однако в последние годы выпуск их значительно сократился.

Диагональ гладкокрашеная - традиционная ткань с подвижной структурой, выработанная диагоналевым (на базе саржи) переплетением из однониточной пряжи средней линейной плотности в основе и утке,

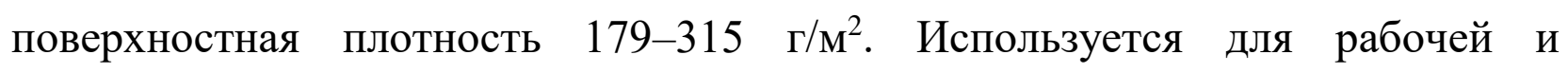
специальной одежды.

Диагональ меланжевая - более тяжелая плотная ткань с малоусадочной отделкой для форменной одежды. Вырабатывается из крученой кардной пряжи в основе и однониточной толстой в утке. Имеет выпуклый двойной рубчик, идущий вверх по диагонали. Поверхностная плотность 240-308 г/м².

Диагональ плащеевая вырабатывается из крученой гребенной пряжи, в отделке проходит водоотталкивающую пропитку. Поверхностная плотность

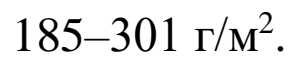

В технологической переработке диагонали просты и не вызывают затруднений, но обладают осыпаемостью, дают усадку по основе до $6 \%$.

Молескин - классическая ткань, гладкая, блестящая, мерсеризованная; вырабатывается усиленным сатиновым переплетением из кардной пряжи низкой линейной плотности. Плотный молескин обладает пыленепроницаемостью. Используется для рабочей одежды - курток, брюк, комбинезонов. Обладает осыпаемостью, незначительной усадкой (1-2\%). Ткань достаточно тяжелая - 170-347 г/м². Эти ткани по своей структуре характерны для XXI века - они намного легче, пластичнее за счет использования пряжи высоких номеров. Незаметные глазу отделки или добавки обеспечивают несминаемость, комфорт, защиту от непогоды и грязи.

Трико вырабатывается из меланжевой пряжи (из волокон, окрашенных в разные цвета до прядения), пряжи из разноцветных нитей вприкрутку с комплексными химическими нитями; характеризуется продольными полосками; вырабатывается комбинированными переплетениями «ломаная» и

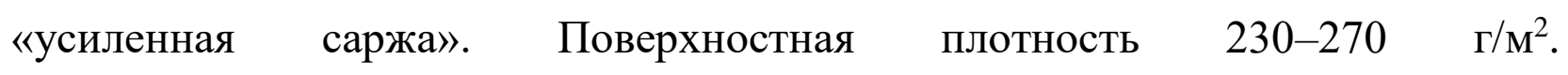
Хлопчатобумажные трико имитируют костюмную шерстяную ткань и используются для недорогих мужских костюмов и брюк. Обладают 
осыпаемостью и некоторой прорубаемостью, поэтому необходим подбор острых игл при переработке этих тканей. Трико - плотная ткань комбинированного или саржевого переплетения с четким рисунком на поверхности в виде рубчиков, клеток или полос. Вырабатывается из хлопка или шерсти, иногда с добавлением искусственных или синтетических волокон. Ткань хорошо держит форму, при раскрое требует учета направления рельефного рисунка.

Коверкот - ткань с малоусадочной отделкой, вырабатывается диагоналевым переплетением из крученой пряжи линейной плотности 18,5 текс х 2 в основе и одноцветной однониточной пряжи линейной плотности 26,3 текс в утке. Поверхностная плотность 232 г/м². Коверко́т - шерстяная или полушерстяная, а также хлопчатобумажная плотная тяжёлая ткань саржевого переплетения с характерным мелким пёстрым узором в рубчик в виде мелких светлых точек на более тёмном фоне.

Джсинсовые ткани (деним) вырабатываются саржевым или мелкоузорчатым переплетением из пряжи средней линейной плотности, одиночной или крученой в основе и однониточной в утке (обычно в основе гладкокрашеная пряжа, а в утке - суровая). Выпускаются также ткани из суровой пряжи в основе и меланжевой в утке. Для придания формоустойчивости и жесткости ткани аппретируются малосминаемыми аппретами. Джинсовые ткани бывают хлопчатобумажные и хлопколавсановые, содержащие 25-33\% волокон лавсана. В настоящее время их выпускают из льна, конопли с добавками химических волокон, и все они, как правило, со стретч-эффектом. Поверхностная плотность 248-375 г/м².

Сегодня джинсовый стиль включает все возможные виды изделий - от пальто, платьев, брюк и курток до аксессуаров и обуви.

Деним отлично вписывается в современные тенденции: комфорт, индивидуальность. Классические джинсовые ткани из натурального хлопка (деним) по-прежнему занимают приоритетные позиции, но в настоящее время могут быть сделаны из хлопка с полиэстром, шелком и другими вариантами синтетических волокон, в том числе волокон нового поколения. При этом современные технологии позволяют создать новые варианты джинсовых тканей - одежду изготовляют из ткани «шамбрей» (поплин или рогожка в джинсовом оформлении), он достаточно плотный, но при этом более легкий и тонкий, мягкий и бархатистый на ощупь; вложение эластановых волокон позволяет изделиям прекрасно сохранять заданную форму. 
Новые технологии ткачества, цвет и свойства пряжи, разнообразные отделки позволяют не только окрасить джинсовые ткани в любые цвета модной гаммы, но и изменить их внешний вид: на поверхности создается мерцающий блеск, имитирующий вкрапления металлизированных волокон; создается денйм с набивными сложными моно-раппортными рисунками и т. д.

К зимней подгруппе одежных тканей относятся хлопчатобумажные сукна, замша, вельветон.

Сукно - наиболее тонкая и мягкая ткань в этой подгруппе, вырабатывается из одиночной кардной пряжи, более толстой в утке, чем в основе. За счет уточной системы образуется густой начес на лицевой стороне. Некоторые сукна изготовляют с вложением химического волокна (капрон, вискоза). Выпускают сукна гладкокрашеными, реже меланжевыми. Поверхностная плотность 303-392 г/м²; например, «Молтон» - мягкая ткань полотняного переплетения, ворсованная с обеих сторон.

Замша - наиболее тяжелая, плотная ткань зимнего ассортимента. Вырабатывается из крученой пряжи по основе и однониточной по утку. На лицевой стороне имеет коротко подстриженный и хорошо запрессованный ворс. Выпускается гладкокрашеной различного цвета. Поверхностная

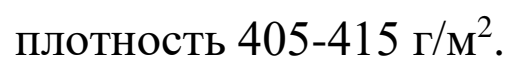

Вельветон вырабатывается также из крученой кардной пряжи в основе и однониточной в утке. Имеет густой, высокий начес за счет уточных нитей. Ткань имеет повышенную плотность, относится к тяжелым тканям (370-400 $\left.\Gamma / \mathrm{M}^{2}\right)$ и выпускается гладкокрашеной, реже - меланжевой.

Bорсовые ткани. В группу входят ткани, выработанные сложным уточноворсовым переплетением. Ткани имеют основу из гребенной или кардной крученой пряжи и чаще всего однониточный уток; на лицевой поверхности имеют разрезной ворс, полученный путем разрезания после ткачества уточных настилочных нитей. Чтобы после разрезания ворса не ослабить уточную систему, ткани вырабатываются с большей плотностью по утку. Для укрепления ворса их с изнаночной стороны аппретируют малосминаемым аппретом. Ворсовые ткани имеют красивый внешний вид, обладают мягким, приятным на ощупь туше, при прочном закреплении ворса обладают хорошей износостойкостью. Вырабатываются гладкокрашеными и набивными, в основном темных тонов. Для придания тканям блеска, мягкости, стойкости ворса к смятию они обрабатываются термореактивными смолами и кремнийорганическими соединениями. 
Вельвет-рубчик имеет на лицевой поверхности мелкие (шириной 1-2 мм) рельефные полоски с коротким (высотой 0,8-0,9 мм) ворсом. Поверхностная

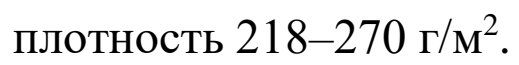

Вельвет-корд имеет на поверхности рельефные полоски шириной 3-5 и

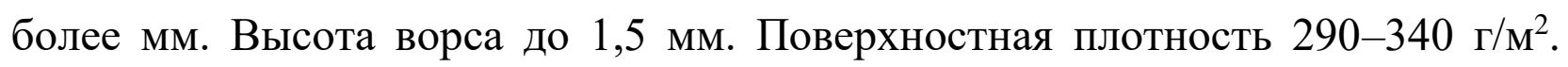
Вельветы для брюк вырабатываются из хлопколавсановой пряжи.

Полубархат имеет ровную ворсовую поверхность из ворсовых уточных нитей. Высота ворса 2 мм, ширина полубархата нерациональна - 53 см. Поверхностная плотность 270 г/м².

Бархат вырабатывают с ворсом из основных нитей. Ширина бархата -

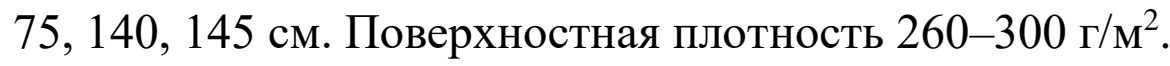

\section{Льняные ткани}

Ткани, изделия, вытканные из льна, обладают прекрасными свойствами чисто экологического продукта, способного поддерживать и питать положительный баланс организма.

Ассортимент бытовых льняных тканей более узок и менее разнообразен по строению и волокнистому составу, чем ассортимент хлопчатобумажных тканей. Для их производства используется пряжа меньшей линейной плотности (117,6-33,3 текс), чем для хлопчатобумажных (33,3-5,8 текс).

Выпускают чистольняные и полульняные ткани. При производстве полульняных тканей используют льняную пряжу в сочетании с хлопчатобумажной пряжей и химическими нитями, а также смешанную пряжу, содержащую штапельные искусственные и синтетические волокна. В зависимости от волокнистого состава полульняные ткани можно подразделить на хлопкольняные, льновискозные и льнолавсановые. Наряду с двухкомпонентными все более широкое применение получают ткани из трехкомпонентной льнолавсановискозной пряжи, содержащей соответственно $34,33,57 \%$ этих волокон. Для бельевых тканей используют полинозное и сиблоновое волокна. (Сиблоновое волокно - модифицированное вискозное волокно. Для выработки его используют однородную по свойствам древесную целлюлозу со степенью полимеризации 500-600).

В настоящее время популярны сочетания лен/вискоза, лен/нейлон, лен/шерсть, традиционные льняные ткани с выраженными непропрядами, ткани типа рогожки, холста и т. д. Создана немнущаяся и более пластичная льняная ткань за счет включения полиуретановых нитей. 
В общем ассортименте льняных тканей по объему выпуска преобладают ткани полотняного переплетения. Используется также мелкоузорчатые и жаккардовые переплетения, иногда саржевые, атласные и рогожка.

Современная структура льняных тканей рыхлая и грубоватая на вид, из толстой, неравномерно окрашенной пряжи, напоминающей «домотканые» ткани. Смесовые ткани вафельного переплетения, пестроткани с эффектом шине (пряжа частичного крашения или печатная), рельефные рогожки по внешнему виду напоминают одновременно лен и шерсть. Лен не скрывает свою фактуру. В меру разреженный, но не слишком подвижный, лишь слегка просвечивающий, упрямо топорчащийся, он демонстрирует неровноту пряжи и окраски как примету натурального происхождения, при этом самый грубый на вид лен оказывается на ощупь мягким, приятным, не раздражающим кожу.

По отделке ткани делятся на суровые, полубелые и белые, гладкокрашеные, набивные, меланжевые, пестротканые, кислованные. При заключительной отделке некоторые костюмно-платьевые ткани подвергают малосминаемой отделке.

«Первобытная» внешность тканей успешно сочетается с новейшими технологиями обработки: от легкого естественного блеска «лаке» или «вощеной» поверхности до покрытий, напылений, печати «под металл», эффектно контрастирующей с суровым льном, подворсовки, придающей льну мягкость и выразительность.

Пропитки полиуретаном навсегда зафиксировали «неглаженый», «свежестираный» вид льна. Именно при помощи отделок новое изделие из льна будет мягким, как ношеное. Таким образом, современный лен - тонкий $u$ легкий, блестящий и мягкий, в богатой насыщенной иветовой гамме.

Конопля и рафия начинают занимать место рядом со льном и развивают те же идеи. Ткани, содержащие лен, крапиву (рами), коноплю, с поверхностью, оживленной длинными штрихами непропрядов, демонстрируют свое растительное происхождение и «первобытную» неровноту окраски. Рисунки очень мелкие или сверхкрупные. Эффекты повторного или частичного крашения довершают индивидуальный облик этих материалов.

Ткани для рабочей одежды вырабатываются плотными и грубоватыми на вид из льна сурового, отбеленного, гладкокрашеного, как правило, темносинего цвета, они легче старинных холстов или парусины, на вид такие же жесткие, однако всегда имеют мягкую отделку; применяется эффект шине, разнообразящий привычные льняные непропряды. 
Все льняные ткани отличаются высокими прочностными показателями и износостойкостью, малой растяжимостью, повышенной жесткостью. Они обладают хорошими гигиеническими свойствами. Благодаря высокой сорбционной и впитывающей способности льняные ткани издавна применяются для нательного, постельного и столового белья. Хорошая паропроницаемость тканей обеспечивает комфортность пододежной среды; они хорошо поглощают потожировые загрязнения кожи, легко стираются и хорошо отстирываются, обладают высокой устойчивостью к многократным стиркам, сохраняя при этом свой красивый внешний вид и белизну (не желтеют). Отличаются повышенной теплопроводностью (создают приятное ощущение свежести и прохлады), что особенно важно для летних платьев и белья. Недостатком льняных тканей являются низкие упругие свойства и поэтому большая сминаемость, во влажном состоянии ткани хорошо отглаживаются.

В зависимости от назначения льняные бытовые ткани и штучные изделия (скатерти, салфетки, полотенца) делят на столовые, бельевые, полотенечные, одежные, декоративные и прикладные.

Блузочные и сорочечные ткани выпускают в основном из хлопчатобумажной пряжи в основе и льнолавсановой в утке. Это тонкие, пластичные полотна с невысокой (до 150 г/ $\mathrm{m}^{2}$ ) поверхностной плотностью. Вырабатывают их разреженной структуры, гладкими, с мелкорельефным или ажурным эффектом, гладкокрашеными или с цветочными рисунками. К примеру, льняная марленка «Акварель» - набивная с просновками, поверхностная плотность 120 г/м², ширина 150 см. Облегченные платьевые ткани вырабатывают мелкоузорчатыми переплетениями с чередующимися плотными и разреженными полосами. Ткани с меланжевым эффектом получают благодаря использованию смеси волокон, по-разному воспринимающих красители. Ткани имеют малосминаемую отделку.

Костюмные ткани от платьевых отличаются большей плотностью и применением крученой пряжи по основе и утку, что улучшает формоустойчивость тканей. Ткани имеют грубоватую структуру и шероховатость, их фактура напоминает домотканые холсты. Поверхностная

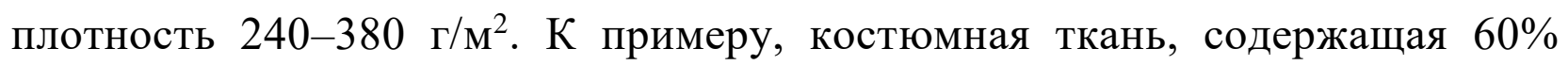
льна, 25\% хлопка, $12 \%$ полиэстра и $3 \%$ эластана, обладает гладкой и эластичной структурой, хорошими деформационными свойствами, низкой усадкой. 
Ткани детского ассортимента вырабатываются с минимальным (до 8\%) содержанием синтетических волокон и не подвергаются малосминаемой отделке. Чаще всего это хлопкольняные ткани с мелким печатным рисунком детской тематики. Их поверхностная плотность 112-190 г/м².

Бортовые ткани (бортовки) используются в качестве прокладок при изготовлении верхней одежды для придания деталям устойчивой формы (бортов, полочек, воротников и др.), упрочнения отдельных участков и предохранения их от деформации.

\section{Шерстяные ткани}

На каком бы уровне ни находилась цивилизация, ткань, изготовленная из шерсти овцы, была и остается «второй кожей» человека, его самым верным защитником. Она всегда популярна и пользуется постоянным спросом.

Шерстяные ткани являются одной из наиболее ценных групп разновидностей тканей. Они красивы, прочны, не мнутся и обладают высшими теплозащитными свойствами. Ведущие дизайнеры мира широко используют шерсть, высоко оценивая ее качество, стиль, драпируемость, мягкость, комфортность, формовочную способность. Привлекает не только тепло пушистой шерсти, но и ее добротность, толщина упругого слоя. Ассортимент шерстяных тканей содержит чистошерстяные и полушерстяные ткани.

К чистошерстяным относятся ткани, состоящие только из шерсти или содержащие до 5\% других волокон или нитей, которые вводятся в нее дня получения каких-либо внешних эффектов.

Полушерстяные ткани отличаются друг от друга по содержанию шерсти, по числу и виду вводимых волокон и по способу их введения. Содержание шерсти в полушерстяных тканях может быть в пределах от 90 до 20\%.

По числу вводимых волокон полушерстяные ткани могут быть двухкомпонентными, если кроме шерсти вводится еще одно волокно, трехкомпонентными и многокомпонентными.

Каждое вводимое волокно влияет на свойства тканей. Так, введение хлопка удешевляет ткани, но делает их более тяжелыми, более сминаемыми, увеличивает усадку и ухудшает внешний вид. Введение вискозного волокна также несколько ухудшает внешний вид, увеличивает сминаемость, ткани плохо держат складки и увеличивается усадка. Но введение хлопка или вискозного волокна придает тканям мягкость и хорошие гигиенические 
свойства. Процентное содержание вискозного волокна в шерстяных тканях может быть различным - от 7 до $70 \%$.

Введение синтетических волокон придает тканям упругость и несминаемосгь. Ткани из шерсти с капроновым волокном обладают повышенной прочностью и стойкостью к истиранию.

Содержание штапельного капрона в шерстяных тканях не превышает 10\%, так как при увеличении процентного содержания капроновых волокон ткани теряют упругость, приобретают повышенный блеск. Ткани с лавсановым волокном имеют меньшую усадку, обладают прочностью, износостойкостью, упругостью, несминаемостью, молестойкостью, стойкостью к действию микроорганизмов и плесени, хорошо держат плиссе и складки, однако они более жесткие, хуже драпируются, сборят в швах, при влажно-тепловой обработке могут давать неустранимые пятна. Процентное содержание лавсанового волокна обычно составляет 40-60\%. Широкое применение, особенно в платьевых тканях, находит добавка нитронового волокна, которое способствует сохранению тканью шерстистости, меньшей пиллингуемости и яркости окраски, устойчивости к смятию и химической чистке, такие ткани хорошо держат складки и дают усадку $20 \%$.

Но ткани с нитроном обладают невысокой износостойкостью, значительной растяжимостью и осыпаемостью. Нитрон вводится в количестве 40-60 \%. Ткани с включением лайкры, придающей дополнительные свойства - несминаемость, эластичность, прочность - уже давно снискали себе популярность, учитывая их практичность и функциональность. Введение синтетических волокон ухудшает гигроскопичность тканей, что приводит к необходимости выработки многокомпонентных тканей.

По новому смотрится обновленная классика в шерсти, кашемире, альпаке и материалах с основой из верблюжьей шерсти. Эти пряжи имеют войлочный и прочесанный вид, а в процессе ткачества образуют фланелеподобную поверхность с размытыми полосами. Войлок или клоке напоминает шерстяная пряжа в смеси с синтетикой, а в смеси с целлюлозой она приобретает упругость и обретает сухое туше и необходимую мягкость. Смесовые пряжи шерсть + шелк или шерсть + вискоза очень мягкие, легкие и объемные. Необычно пушистая, мериносовая шерсть становится невесомой. Ощущение уюта усиливается за счет использования ворсистых нитей с мохером, а буклированные поверхности начесываются, шлифуются с двух сторон. На пряжах появился слой металла. Ламинированное покрытие заменено новыми 
возможностями окисления. Для придания эффекта свечения в пряжи неравномерно включают оксидные металлизированные добавки.

В зависимости от вида используемых нитей шерстяные ткани делятся на камвольные (гребенные), тонкосуконные и грубосуконные.

Камвольные ткани вырабатывают из сравнительно тонкой и гладкой пряжи: чистошерстяной однониточной суровой и крашеной линейной плотности 22-36 текс, смешанной однониточной суровой и крашеной линейной плотности 20-42 текс, чистошерстяной крученой суровой и крашеной линейной плотности 15,5 текс х 2, 42 текс х 2, смешанной крученой суровой и крашеной линейной плотности 21 текс х 2, 4 текс х 2 . Камвольные ткани имеют гладкую поверхность с четким ткацким рисунком, плотны, упруги, но жестковаты. Эти наиболее тонкие и легкие ткани выпускаются с относительной плотностью 70-140\%, их вырабатывают саржевым и комбинированным, а также жаккардовым и полотняным переплетением. Популярна полоска - пестродробная или неровного цвета. Точечные пунктирные проблески цвета создают выразительный эффект чешуйчатых сеток и клеточек. Для создания материалов используются фасонные пряжи высокой сложной крутки и нити с филаментными полосками.

Тонкосуконные ткани вырабатывают из тонкой и пушистой аппаратной пряжи, чистошерстяной и смешанной, однониточной линейной плотности 50-330 текс и крученой линейной плотности 64 текс х 2, 170 текс х 2 . Тонкосуконные ткани уваливают, ворсуют. Ворс уваливают, подстригают, запрессовывают. Ткацкий рисунок чаще всего виден плохо, ворс в той или иной степени его закрывает. Эти ткани рыхлые, мягкие и эластичные, хорошо носятся, красивы по внешнему виду.

Малоплотные и рыхлые тонкосуконные ткани имеют повышенную растяжимость, затрудняющую их настил и пошив. По характеру расцветки шерстяные ткани вырабатываются гладкокрашеными, пестроткаными, меланжевыми, напечатанными.

Крепы - классические тонкие малоплотные ткани креповых и других мелкоузорчатых переплетений с матовой мелкозернистой поверхностью, выработанные из пряжи высокой крутки. Выпускаются гладкокрашеными (в широкой гамме цветов, включая яркие и насыщенные светлые тона).

Чистошерстяные крепы сложны в швейной обработке, так как сильно растягиваются, перекашиваются, осыпаются и дают значительную усадку. 
Жаккардовые крепы - ткани узорчатых переплетений с ткацкими рисунками геометрического, растительного или орнаментального характера;

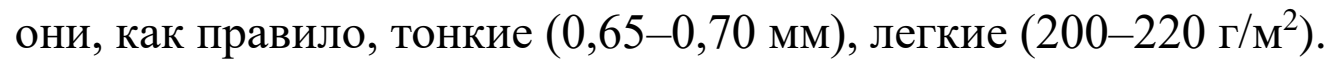

Набивные платьевые ткани вырабатываются в основном из одиночной пряжи полотняного, саржевого или крепового переплетений с печатным рисунком по суровому или гладкокрашеному фону, причем только на лицевой стороне ткани производят набивку; ткани выпускаются с малой толщиной (0,3-0,5 мм) и небольшой поверхностной плотностью (100-160 г/ м $\left.^{2}\right)$.

Комбинированные платьевые ткани вырабатываются сложными переплетениями с рельефным узором, просвечивающими, с продольно и поперечно чередующимися полосами полотняного и крепового переплетения. Новый ассортимент включает малоплотные ткани мелкоузорчатых переплетений с металлическими и металлизированными нитями.

Фланели - современные чистошерстяные - пани, выработанные полотняным или саржевым переплетениями в меланжевом или пестротканом оформлении, имеющие на поверхности достаточно плотный ворсовой настил, поэтому толщина их 0,8-0,85 мм и поверхностная плотность 230-240 г/м $\mathbf{m}^{2}$.

Ткани с применением альпаки, ангоры, кашемира, верблюжьей шерсти в процессе ткачества приобретают фланелеобразную поверхность с размытыми плоскостями, вышивкой или перфорацией. Шерсть в смеси с целлюлозой приобретает упругость и имеет сухое туше, но сохраняет мягкость. Новые предложения можно найти в мягких, легких и очень объемных тканях, выполненных из смеси шерсти и шелка, шерсти и вискозы. Мягкость достигается за счет использования ворсистых нитей во главе с мохером, а буклированная поверхность для наибольшей пушистости начесывается и шлифуется иногда с обеих сторон.

К классическим полушерстяным тканям относятся кашемиры, шотландки и крепы.

Камемир - мягкая, легкая равноплотная ткань саржевого переплетения; гладкокрашеная, выработанная из гребенной смешанной пряжи, содержащей шерсть, вискозу и нитрон (капрон). Обладает хорошим видом, достаточно формоустойчива, износостойка, но несколько сминаема. Применяется для детских, школьных и женских платьев.

Шотландка - наиболее распространенная классическая зимняя ткань с рисунком в крупную клетку из цветных нитей основы и утка, шерсти с нитроном, лавсаном, а также их сочетания с вискозными нитями, саржевым 
или мелкоузорчатым переплетением. В качестве просновок при образовании клеток иногда применяют фасонную пряжу. Ассортимент представлен тканями с широким диапазоном поверхностных плотностей от легких

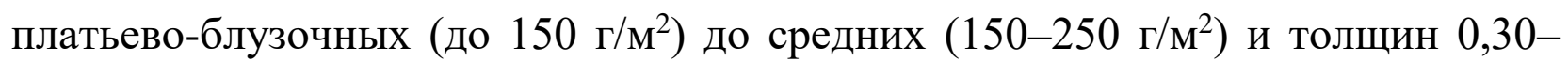
0,50 мм, при этом они чрезвычайно разнообразны по оформлению от ложнооднотонных, меланжевых до многоцветных смежных клеток и полос с различными просновками. Недостатком является осыпаемость и раздвигаемость нитей, особенно у легких тканей.

Kpenь полушерстяные представляют в ассортименте платьевых тканей значительную группу, используемую для изготовления женских повседневных, деловых и нарядных модных изделий. Большинство крепов имеет крученую в два сложения пряжу в основе, а некоторые также и в утке. Применение крученой пряжи и синтетических волокон делает эти ткани износостойкими, немнущимися. Вырабатываются они креповым, жаккардовым переплетениями либо с чередованием различной плотности переплетений (полотняного и атласного, крепового и атласного). По отделке это в основном гладкокрашеные, пестротканые и некоторые - с набивным рисунком. Значительное место отведено креповым структурам со сквозными эффектами. Мягкие, легкие и воздушные полотна хранят следы печатного орнамента, выцветшего от времени.

Легкие тонкие шерстяные ткани играют в зимнем сезоне доминирующую роль. Среди них новые крепы и джерси из кашемира, обсыпанные гранулами, имитации вышивки, лоскутной техники, высокой печати, ришелье и макраме, жаккард с нанесением светлого или радужного металлопластика.

Джерси́ (англ. jersey - от названия острова Джерси) - ткань, основовязаный (из многих нитей) трикотаж из шерстяных, хлопчатобумажных, шелковых или синтетических нитей. Обладает определенной эластичностью и способностью растягиваться. Вес может варьироваться от легкого шелкового полотна для нижнего белья до тяжелого шерстяного джерси, из которого шьют пиджаки и даже пальто.

Камвольные чистошерстяные костюмные ткани: поверхностная плотность 170-340 г/м². Традиционными являются бостон, креп, трико; к новым можно отнести ткани с использованием нетрадиционных видов сырья ангорской шерсти, а также поярковой и цигайской.

Бостон - высококачественная ткань саржевого переплетения, гладкокрашеная, из крученой тонкой и полутонкой гребенной пряжи в основе 
и утке. Ткань упругая, малосминаемая, хорошо сохраняющая форму и размер изделия, обладает хорошей устойчивостью к истиранию. Имеет недостаток явление блеска в местах, подвергающихся при эксплуатации трению.

Kpen - неравноплотная ткань из тонкой и полутонкой крученой пряжи, крепового или атласного переплетения, с мелким двойным плотным рубчиком, выпускается гладкокрашеной, отличается некоторой пушистостью и используется для мужских вечерних костюмов.

Трико - наиболее распространенный вид костюмных тканей. Вырабатывается саржевым, полотняным и комбинированным переплетениями, чаще из крученой пряжи. Особенностью этого вида тканей является большое разнообразие их внешнего оформления. Трико выпускают пестротканым, в полоску и клетку, меланжевым и гладкокрашеным. В последнее время наметилась тенденция к облегчению трико: ткань вырабатывается полотняным переплетением, рисунок в виде полоски или клетки создается чередованием гладкокрашеных и меланжевых нитей. Некоторые виды трико вырабатываются с применением химических профилированных нитей, создающих эффект искорки для нарядных тканей.

Камвольные полушерстяные костюмные ткани. Типовыми являются твид, шевиот и диагональ, а также креп.

Твид - важнейшая из костюмных тканей: рыхлая структура включает пряжи различного состава, характера и цветовой гаммы. Эпонж и объемная переслежистая пряжа выделяется на фоне более тонких нитей, матовый хлопок и лен контрастируют с блеском вискозы, полиамида и золотого или цветного люрекса. Неровная, грубоватая «домотканая» поверхность ткани облагораживается изысканным колоритом - высветленными или припыленными пастельными тонами. Твид, комфортный и элегантный, «родился» в Шотландии, и его название происходит от реки Твид. В настоящее время этим словом называются все ткани, изготовленные из аппаратной пряжи, имитирующие ручную работу и имеющие шероховатую поверхность и характерную цветовую гамму. Поверхность ткани может быть пронизана узелками или отличаться живописным колоритом благодаря разноцветной уточной нити.

Для деловой, повседневной одежды и вечерних костюмов предлагаются твиды, которые сочетают в себе рустикальность с воздушностью завитушек и мохера. К примеру, ткань «Вояж» - артикул С-170-ИА (шерсть - 64\%, мохер 11\%, капрон - 15\%, нитрон - 10\%), поверхностная плотность 399 г/м², ширина 
152 см. Твиды, украшенные блестящими нитями по пушистой поверхности или большими окрашенными прядями из отрезков поливинилхлоридных нитей, отвечают всем желаниям и вкусам: ворсистые, шелковистые, сухие и шлифованные, окрашенные в натуральные цвета и почти флюористирующие, жесткие и растяжимые, матовые и блестящие.

Существует большое разнообразие имитации твида, к примеру коверкот ткань, напоминающая твид, с характерным мелким пестрым узором, возникающим в результате сочетания нитей основы одного цвета с двумя нитями утка различных цветов (черный и белый); шеврон - ткань с характерным рисунком «елочка» - также напоминает твид, особенно те варианты, которые ткут из пряжи шевмот, подбирая для основы и утка контрастную или близкую по цвету серо-черную шерсть. Современные варианты ткани «диагональ» саржевого переплетения, выполненные из фасонной пряжи, также относятся к семейству твидовых тканей. «Лейс-твид» - кружевная, легкая, объемная, одновременно наполненная на ощупь, уток этой ткани выработан из пряжи, напоминающей ровницу, а основа - из тонкой крученой нити.

Шевиот - вырабатывается из неоднородных нитей, скрученных из шерстяной и хлопчатобумажной пряжи, саржевым переплетением и используется для ведомственных костюмов. Поверхностная плотность тканей от 314 до 422 г/м², ширина 136 и 142 см. Отличаются жесткостью и сминаемостью.

Шевио́т - плотная, тонкая, ворсистая ткань, производимая из шерстяной или смешанной пряжи, получаемой камвольным способом. Ткань вырабатывается саржевым переплетением. Традиционный шевиот изготавливается из шерсти шевиотских овец или других мериносоподобных овец

Тонкосуконные костюмные ткани. Вырабатываются полушерстяными из

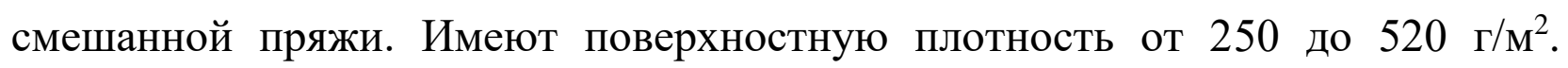
Обладают повышенными теплозащитными свойствами и используются для зимних костюмов и пиджаков.

ПАЛЬТОВЫЕ ТКАНИ вырабатывают с поверхностной плотностью от

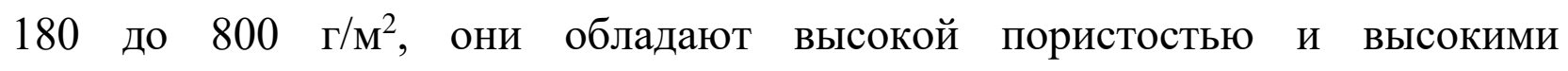
теплозащитными свойствами. В зависимости от вида используемой шерстяной пряжи их подразделяют на камвольные, тонкосуконные и грубосуконные. Ткани зимнего сезона в целом остаются мягкими и 
пластичными, но становятся более плотными, в ряде случаев немного более тяжелыми, обеспечивающими наилучшие теплозащитные свойства.

Камвольные ткани вырабатывают из гребенной или камвольной пряжи. Для этих тканей характерна гладкая, открытая поверхность с четко выраженным ткацким рисунком.

Габардин - гладкокрашеная ткань, саржевого переплетения из крученой пряжи, плотная, упругая, сравнительно легкая. На лицевой поверхности мелкие плотно лежащие выпуклые рубчики, идущие снизу вверх слева направо. Ткань неравноплотная с высоким линейным заполнением, достигающим по основе 140\%. Ширина ткани 142 см, поверхностная плотность 270-440 г/м². Габардины - наиболее сложные в обработке ткани, так как сильно сыпучи, прорубаются, трудно сутюживаются, дают ласы при влажно-тепловой обработке.

Букле - классическая гладкокрашеная ткань, с мелкорельефной лицевой поверхностью для женских зимних пальто. Вырабатывается сложным переплетением из крученой пряжи или однослойными переплетениями из фасонной пряжи. Букле хорошо принимает нужную форму, но обладает сыпучестью и повышенным растяжением. Новые ворсовые букле исполнены в пестроткани с крупными «тающими» полосками и клетками. Букле с мохером придает одежде особый уют и позволяет зимой выглядеть по весеннему ярко и модно. Букле с необычно крупными петлями из разноцветных пряж особенно актуальны в настоящее время. К примеру: ткань буклированная ворсовая «Сказание» - артикул С162-ИА (шерсть - 50\%, мохер - 20\%, капрон - 15\%, нитрон - 15\%), поверхностная плотность 460 г/м², ширина 152 см; буклированная ворсовая ткань, артикул С-160-ИА - «Легенда» (шерсть - 40\%, мохер - 20\%, капрон - 10\%, нитрон - 30\%), поверхностная плотность 393 г/м², ширина 152 см; буклированная ткань «Элегия», артикул С-155-ИА (шерсть - 50\%, мохер -

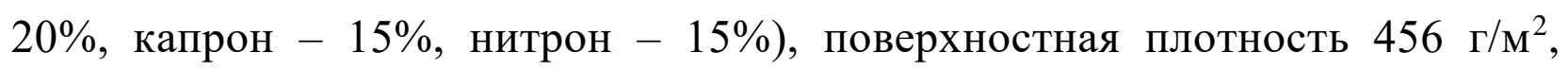
ширина 152 см.

Жаккардовая пальтовая ткань - сравнительно тонкая рельефная ткань, жесткая. Иногда вырабатывается полутораслойной, с использованием в изнаночном слое аппаратной пряжи. Дополнительное оживление вносят вкрапления фасонной, шине или объемной пушистой пряжи (акриловой, вискозной), усиливающие контраст фактур и разнообразие рельефа в жаккардовой ткани. При этом матовость и теплое туше придает таким тканям 
небольшой процент хлопка или льна, входящих в структуру, как правило, в сочетании с полиэстром, вискозой или полиамидом.

Тонкосуконные пальтовые ткани. Вырабатывают из аппаратной пряжи. Поверхность тканей частично или полностью покрыта ворсом. Ткани разделяют на драпы, сукна и пальтовые. Небольшая часть их вырабатывается чистошерстяными. Значительно больше полушерстяных тканей.

Классические ворсовые ткани отличаются густым и шелковистым ворсом, гладкой блестящей поверхностью, уникальными теплозащитными свойствами, вложением дорогих видов сырья (мохера, альпаки). Нетрадиционное оформление ворсовых тканей рельефным рисунком делает их более декоративными. Разнообразие чистых цветов и оттенков позволяет гармонично сочетать ткань с мехом.

Драпь - толстые тяжелые ткани, получившие большую увалку. В этом случае их поверхность полностью закрыта войлокообразным застилом, драпы чаще выпускаются гладкокрашеными. Пестротканые драпы получают небольшую увалку и сохраняют открытым ткацкое переплетение. Большинство драпов ворсуют с лицевой стороны, а некоторые с обеих сторон. Поверхность драпов может быть начесана, и ворс подстрижен. У некоторых драпов (ратины, флаконэ) после подстрижки на сравнительно большую высоту ворс закатывается (ратинируется) в виде рисунка в рубчик, елочку, горошек и др.

Драпь вырабатываются саржевыми, сатиновыми, атласными и комбинированными переплетениями. Это легкие однослойные драпы. Более тяжелые драпы вырабатывают сложными полутораслойными и двухслойными переплетениями. Чистошерстяные драпы вырабатывают из одиночной и крученой аппаратной пряжи. Объемные ткани, толщиной сравнимые с одеялом, оказываются легкими, словно наполненными воздухом; ткани плотные, компактные, падающие выразительными «свинцовыми» складками, остаются необычайно тонкими. Особую группу составляют двухслойные двухлицевые ткани, гладкокрашеные или жаккардовые.

Полушерстяные драпы вырабатывают из смешанной пряжи, содержащей вискозное, капроновое, лавсановое, нитроновое волокно. Такие драпы, как велюр, ратин, кастор, моренго и другие высококачественные драпы, используются для изготовления мужских и женских пальто и характеризуются хорошими теплоизоляционными свойствами и высокой износостойкостью. 
Драпы и ткани с касторовой отделкой имеют направленный ворс и едва уловимый блеск - элегантны и сдержанны, формоустойчивы и комфортны. Их легко носить, за ними легко ухаживать. К примеру: ткань с касторовой отделкой «Очарование» - артикул С-108-ИА (шерсть - 90\%, капрон - 10\%), поверхностная плотность 496 г/м², ширина 152 см; драп «Успех» - артикул С-

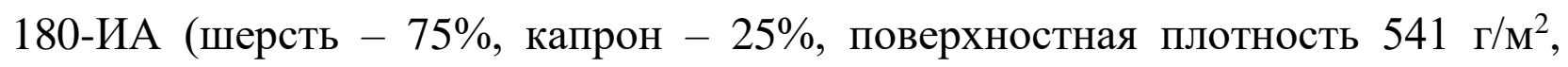
ширина 142 см); ратин «Премьер» - артикул С-168-ИА (шерсть - 85\%, капрон - 15\%), поверхностная плотность 599 г/м².

Сукна - однослойные ткани полотняного или саржевого переплетения, сильно уваленные, с войлокообразным застилом из начесанного ворса. Сукна выпускают гладкокрашеными и используют для ведомственной одежды.

Пальтовые ткани легче сукон и драпов. Чистошерстяных пальтовых тканей немного. Это гладкокрашеные мягкие ткани с гладкой короткостриженой ворсовой поверхностью.

Фуле и фланели - ткани саржевого или полотняного переплетения, мягкие, с небольшим ворсом. Большую часть пальтовых тканей составляют полушерстяные из смешанной пряжи. Они очень разнообразны. Большая их часть предназначается для детских и женских пальто. Пальтовые полушерстяные ткани легче чистошерстяных, более тонкие. Преобладают пестротканые - с рисунком в клетку, с рельефными рисунками из фасонных нитей, из нитей, скрученных из разноцветной пряжи. В смешанной пряже используется капроновое и нитроновое волокно.

Грубосуконные пальтовые ткани вырабатывают из неоднородной грубой и полугрубой шерсти. Это тяжелые ткани с поверхностной плотностью 600-760 $\Gamma / \mathrm{M}^{2}$. Классической грубосуконной чистошерстяной тканью является бобрик ткань атласного переплетения с короткостриженым вертикально расположенным упругим ворсом. Основную массу тканей этой подгруппы составляют шинельные сукна, содержащие 70-85\% шерсти. Ткани полотняного переплетения с войлокообразной поверхностью очень жесткие, гладкокрашеные.

Кроме перечисленных групп тканей, в шерстяной промышленности вырабатывают штучные изделия: платки, шарфы, пледы, одеяла, скатерти, а также технические ткани - фильтровальные, сукна для печатных машин и др.

Изделия из пальтовых тканей, драпов, сукон и т.д. устойчивы ко всем органическим растворителям для удаления пятен химической чистки. Влажнотепловую отделку изделий из велюровых и ратинированных драпов следует проводить на паровоздушном манекене. 


\section{Шелковые ткани}

К шелковым относятся ткани не только из нитей натурального шелка, но и из химических волокон, на долю которых приходится около $98 \%$. Ассортимент шелковых тканей очень обширен и разнообразен по всем показателям (по сырью, видам нитей, переплетениям, плотности, отделке, художественно-колористическому оформлению и др.).

Очень разнообразен ассортимент шелковых тканей по волокнистому составу, они вырабатываются как в чистом виде, так и в смеси с другими волокнами: натурального шелка, хлопка, шерсти, вискозы, ацетатными, триацетатными, капроновыми, лавсановыми, нитроновыми, хлориновыми, ацетохлориновыми, полипропиленовыми, металлическими и метанизированными. Не менее разнообразен ассортимент шелковых тканей по видам применяемых нитей: шелка-сырца, основы, утка, муслина, москрепа, крепа, спирали, эпонжа, эластика, акона, аэрона и др.

Шелковые ткани вырабатываются из очень тонкой пряжи (1,55-16,6 текс), одинарной и крученой, правой и левой крутки, пологой, средней, повышенной и высокой крутки. По структуре поверхности бывают гладкие и ворсовые; переплетения разные, чаще всего полотняное и атласное, мелкоузорчатые, сложные, жаккардовые; плотность колеблется в широких пределах от прозрачных до непрозрачных - "35-90\%; ширина - 70-150 см;

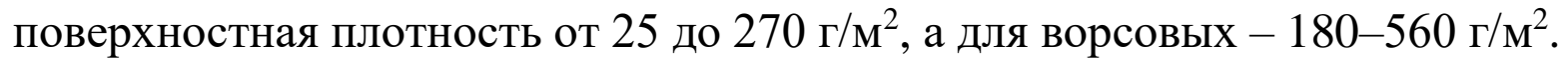

Шелковые ткани характеризуются большим разнообразием по художественно-колористическому оформлению: суровые, отваренные, отбеленные, гладкокрашеные, мулинированные, пестротканые, с различными видами набивки, с эффектами клоке и гофре, тисненые, вытравные, флокированные, с креповым эффектом, жатости, шанжан и др.

Ткани из натурального шелка отличаются красивым внешним видом, приятным блеском, мягкостью, упругостью, малой сминаемостью, легкостью, прочностью, гигиеничностью. Недостатком является то, что при смачивании эти ткани дают большую усадку, особенно креповые $(15 \%)$. Эта усадка «кажущаяся » и при глажении в мокром состоянии и натяжении ткани расправляются и приобретают почти прежние размеры. Кроме того, они гладкие, скользкие, легко растягиваются, осыпается, что затрудняет их раскрой и пошив.

Как принято в практике, в зависимости от волокнистого состава шелковые ткани подразделяются на группы: из шелковых нитей; из шелковых 
нитей с другими волокнами; из искусственных нитей; из искусственных нитей с другими волокнами; из синтетических нитей; из синтетических нитей с другими волокнами; из искусственных волокон и в смеси с другими волокнами; из синтетических волокон и в смеси с другими волокнами; ткани, изготовленные тканевязанным способом.

Группы в свою очередь делятся на следующие подгруппы: креповую, гладьевую, жаккардовую, ворсовую, специальную, технические ткани и штучные изделия.

По назначению шелковые ткани подразделяются на платьевые, сорочечные, блузочные, костюмные, плащевые, мебель-но-декоративные, подкладочные, технические и т.д.

Ткани из шелковых нитей не отличаются большим разнообразием. Они вырабатываются шириной 75-145 см, поверхностной плотностью 25-100 г/м². Наибольший удельный вес составляют креповые ткани. Они имеют красивый внешний вид, хорошую драпируемость, зернистую поверхность вследствие применения нитей креповой крутки. Наиболее характерными тканями этой подгруппы являются: креп-шифон, креп-жор-жет, крепдешин. Гладьевые ткани вырабатываются в основном полотняным переплетением, некоторые атласным из пряжи шелка-сырца, муслиновой, основы, утка, креповой. К ним относятся: полотна, ткани платьевые, атласы, чесуча, фуляры (используются для женских костюмов, платьев, блузок, халатов, сорочек). Жаккардовые ткани - это в основном платьевые и блузочные ткани жаккардового переплетения.

Ассортимент шелковых тканей отличается большим разнообразием используемых нитей, структур и видов отделки. Отсюда и разнообразие их свойств и большой диапазон величин поверхностной плотности. Большинство полушелковых тканей - смесовые: в них сочетается шелк с вискозой или полиэстром, с хлопком, вискоза с хлопком, полиэстр с хлопком, и практически всюду лайкра или эластан.

Лайкра - необычное прозрачное волокно, его не видят, но ощущают. Даже небольшое количество лайкры многое меняет в структуре и свойствах ткани. Достаточно добавить в смески 2\% лайкры, чтобы существенно улучшить качество одежды - обеспечить 20\% эластичности, приводящей к другому уровню комфорта, увеличить срок ее эксплуатации, добавить изящной облегаемости, отличной формоустойчивости и драпируемости. Лайкра - это популярнейший бренд полиуретанового волокна, который 
является детищем американской химической компании "DuPont", а точнеe, ee части - фирмы "Invista". По сути, это тот же спандекс, как принято говорить в Канаде и США, и эластан - в русской традиции. Если говорить о строении данного материала, то лайкра является сегментированным полиуретаном, который относится к искусственным эластановым волокнам. Они состоят из гибких сегментов, соединенных между собой своеобразными "мостами" жесткими связями. Именно они предохраняют волокно от разрывов мягких сегментов, за счет чего материал и становится эластичным.

Новое поколение волокон (hi-tech) 90-х обладает замечательными свойствами. Самые молодые имена в «синтетическом» семействе - тенкель, тактель, лайкель - они соединили в себе все лучшие черты природного и синтетического. Тенкель до неузнаваемости изменил облик привычной синтетики, сделав ткани мягкими, легкими, шелковистыми (имитация натурального шелка).

Тактель - новинка, полученная на основе нейлона - имеет безграничные возможности. Можно смешивать и с синтетикой, целлюлозой, в результате улучшается качество натуральных тканей, появляется превосходный гриф и комфорт при эксплуатации. Созданы интересные и подвижные поверхности и ткани нового качества. Волокно тактель имеет несколько видов. Так, изделия из тактеля «Мультисофт» очень легкие и мягкие на ощупь, отличаются особой прочностью, а тактель «Микро» применяется в производстве тканей, стойким к атмосферным воздействиям, которые при этом «дышат», обладают исключительной мягкостью, изысканным внешним видом. Тактель «Диаболо» за счет профилированного поперечного сечения нити придает текстилю отличную драпируемость, радужный глянец и эффект шан-жан.

Лайкель - это, во-первых, заменитель целлюлозного волокна, оно очень прочное, но, между тем, способно к биологическому разложению, отслужив свой век - для синтетики это невиданное качество; во-вторых, имеет способность к мелкому разветвлению волокон, а это значит, что ткань из него - подлинный хамелеон, способный менять свое «лицо» и принимать различные образы - от шелка до замши («дюветин») или «по-де-пеш» (кожа персика), с мягкой бархатистой поверхностью; в-третьих, в мокром виде становится очень прочным; в-четвертых, ткани с применением этого волокна при попадании на них влаги разбухают, образуя преграду дождю и снегу и в то же время они пропускают воздух. 
Шелковые ткани вырабатывают разнообразными переплетениями, но чаще всего применяют полотняное, саржевое, атласное, мелкоузорчатое и крупноузорчатое переплетения. Сложными ткацкими методами авторы добиваются имитации набивного рисунка. Саржевые и атласные переплетения тканей позволяют создавать едва заметные изменения цвета за счет фактуры. Обращает внимание тонкость и разнообразие приемов оформления, используемых для шелкового ассортимента.

По характеру расцветки и отделки шелковые ткани выпускают белеными, гладкокрашеными, меланжевыми, мулинированными, пестроткаными, напечатанными, гофрированными, вытравными, с несминаемой, малоусадочной и водоотталкивающей отделкой. Важный элемент - блеск: шелк натуральный и искусственный, атлас «дюшес» (очень плотный и гладкий); отделка лаке или лощение, лаковые полосы, «зеркальные» покрытия, и «мокрые» ткани.

По структуре поверхности шелковые ткани могут быть гладкими и ворсовыми.

Шелковые ткани чаще других используются для нарядной одежды и должны по своему внешнему виду соответствовать направлению моды и удовлетворять эстетические потребности человека.

По назначению шелковые ткани можно условно разделить на следующие группы: платьево-блузочные, платьево-костюмные, одежные, сорочечные, подкладочные, плащевые и курточные, декоративные и ткани для текстильной галантереи. Кроме этого, в промышленности вырабатываются штучные изделия (покрывала) и технические ткани.

Ткани из шелковых нитей представляют собой группу тканей, выработанных из натурального шелка, шелка-сырца линейной плотности 1,56-2,33 текс, шелка-основы, шелка-утка, шелка-крепа и шелковой пряжи. Структура и колористическое оформление тканей весьма разнообразны, их поверхностная плотность 14-190 г/м². Выпускают в основном малоплотные ткани полотняного переплетения, которые отличаются красивым видом, приятным блеском, мягкостью, пластичностью, прекрасной драпируемостью, небольшой поверхностной плотностью, упругостью, высокой прочностью и хорошими гигиеническими свойствами. Обладают большой растяжимостью, достигающей 25-32\%, при смачивании дают усадку до $15 \%$.

Креповая подгруппа включает классические креповые ткани: крепшифон, креп-жоржет, крепдешин, креп-сатин, креп-гофре и ткани нового 
ассортимента. Мелкозернистую поверхность, растяжимость и эластичность, подвижность структуры и хорошую драпируемость таким тканям придает креповая крутка нитей.

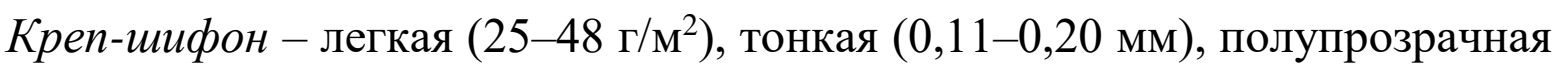
ткань из натурального шелка полотняного переплетения из двух-, трехниточной шелковой нити креповой крутки; выпускают гладкокрашеной, отбеленной и набивной, она отличается подвижной, несколько разреженной структурой с мягким шероховатым грифом. Используется для изготовления платьев, блузок, шарфов и деталей отделки (бантов, жабо, кокилье и др.). К примеру: артикул 10168 (El desing (Элдесинг) 100\% натуральный шелк, для

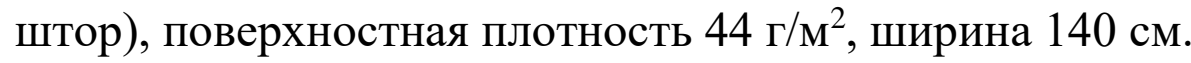

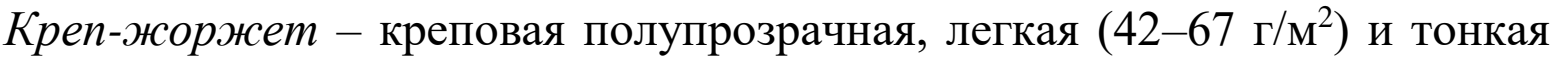
(0,14-0,28 мм) ткань полотняного переплетения из трех- и четырехниточного крепа в основе и утке с мелкозернистой матовой шероховатой поверхностью; отличается подвижностью, пластичностью, большей размеростабильностью по сравнению с креп-шифоном, обладает жестковатым грифом, осыпается. Используется для изготовления платьев, блузок, шарфов, платков, деталей отделки (бантов, жабо и др.).

Крепдешин - классическая полукреповая ткань полотняного переплетения, имеет высокое линейное заполнение и вырабатывается из шелка-сырца пологой крутки в основе и креповой нити в утке; отличается мягким характерным блеском, мягкостью, эластичностью, хорошей драпируемостью. Колористическое оформление крепдешина очень разнообразно, его выпускают гладкокрашеным, отбеленным и набивным разнообразными по форме и расцветке рисунками. Поверхностная

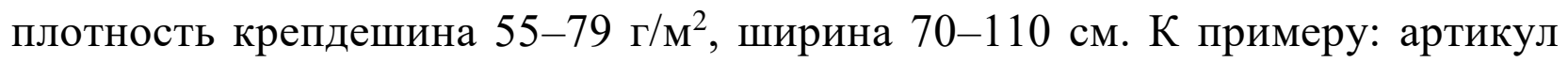
11077 (Шифон - 100\% натуральный шелк), поверхностная плотность 70 г/ $\mathrm{M}^{2}$, ширина $-140 \mathrm{cм}$.

Kpen-сатин - полукреповая плотная, тяжелая (89-97 г/м²) ткань атласного переплетения из шелка-сырца в основе и шелка-крепа в утке, поэтому одна сторона ткани гладкая блестящая, а другая матовая креповая; хорошо драпируется, образуя тяжелые складки. Выпускают гладкокрашеной, используют как двухстороннюю ткань для вечерних торжественных платьев и платьев-костюмов.

Kpen-гофре - ткань, выработанная на базе креп-жоржета или крепдешина, отличается характерной поверхностью с продольной 
морщинистостью (эффект жатости), образуемой за счет использования по утку нитей с разной степенью креповой крутки, обладающих в связи с этим различной величиной усадки. Характеризуется пластичностью в поперечном направлении, растяжимостью, возможностью усадки.

Тонкие упругие практичные смесовые ткани с сухим или скользящим туше хорошо держат форму, а нарядными выглядят за счет актуальных отделок - лаке, тиснения, металлического напыления. Популярна ткань шантунг - упругая типа чесу-ч й с включением пряжи из оческов шелка, неравномерные утолщения которых оживляют блестящую поверхность, предлагается в пестротканом варианте или с эффектом шанжан, с вышивкой, аппликацией или отделкой «соломкой». Такие ткани требуют особого внимания к обработке срезов и современного рационального кроя с минимумом швов и вытачек [34].

Гладьевую подгруппу объединяют ткани с ровной гладкой поверхностью, выработанные из шелка-сырца, слабо-крученного шелка и шелковой пряжи пологой крутки.

Ассортимент этих тканей представлен в основном шелковыми полотнами, которые могут иметь в основе и утке пряжу из натурального шелка и обладают слабым блеском, большой мягкостью и незначительной сминаемостью. Кроме полотен, в ассортимент гладьевых тканей входят фуляры, туали и др., которые имеют в основе шелк-сырец, а в утке - нить невысокой крутки. Все они отличаются большой мягкостью, поверхностная плотность их колеблется от 33 до 70 г/м², а ширина - в пределах 92 см. По отделке ткани могут быть гладкокрашеными, набивными и пестроткаными, используются они для изготовления женских платьев, костюмов, блузок, мужских рубашек и др.

Атлас - плотная ткань с гладкой блестящей лицевой поверхностью, компактная гладкокрашеная или набивная, обладает блеском, создает драпировки.

Шелк-полотно - ткань полотняного переплетения, плотная, непрозрачная, отбеленная, суровая или с печатными рисунками, выработана из шелковой пряжи, хлопкоподобная с мягким шелковистым блеском. Внешне ткань похожа на штапельное полотно, но она тоньше и меньше сминается. Поверхностная плотность у нее от 60 до 100 г/ м $^{2}$, толщина 0,2-0,3 мм.

Востребованы модой все пластичные драпируемые скользящие классические и новые ткани: муслин, шифон, фуляр, та-уль - матовые, мягко 
мерцающие или блестящие и переливающиеся, имеют насыщенные колорит, набивное или пестротканое оформление.

Муслин - тонкая прозрачная ткань, вырабатываемая из однониточного натурального шелка средней (муслиновой) крутки, применяется для изготовления платьев, блузок, легких театральных костюмов.

Шифон - тонкая легкая ткань, вырабатывается гладкокрашеной или набивной и используется для изготовления блузок, платьев. Популярны шифоны с набивными «кашмирскими» рисунками - традиционные «огурцы», стилизованные «индийские цветы», сочетание тех и других мотивов и просто причудливо вьющиеся орнаменты. К примеру, шифон «Нежность» - артикул 10168 (100% натуральный шелк).

Фуляр, туаль - отбеленные или гладкокрашеные тонкие легкие и мягкие ткани полотняного переплетения из шелка-сырца в основе и шелка в утке.

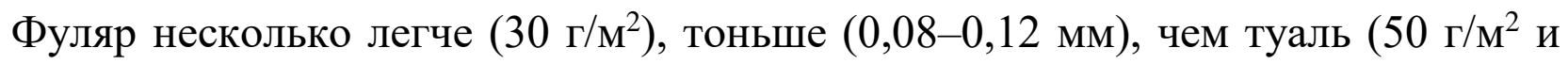
0,12-0,16 мм). К примеру: тауль - артикул 12008/10 (100\% натуральный шелк), поверхностная плотность 472 г/м², ширина 95 см.

В жаккардовую подгруппу входят плотные декоративные ткани - штофы, которые традиционно выпускаются с крупными печатными или орнаментными рисунками: цветочными, мелкими геометрическими двухцветными, «галстучными». Блестящие шелковые ткани вызывают ассоциацию со всевозможными цветными металлами. Жаккардовые переплетения позволяют создать игру фона и цветов, за счет этого ткань смотрится благороднее и объемнее. На ощупь материалы довольно жесткие, но не требующие особого ухода. Дополнительное оживление вносят вкрапления фасонной, шине или объемной пушистой пряжи, усиливающие контраст фактур и разнообразие рельефа в жаккардовой ткани. Полосами выделяется тонкий жаккардовый орнамент по мотивам «кашмирских» рисунков. Пестротканые и жаккардовые рисунки объединяются, создавая единый эффект. Матовость и теплое туше придает жаккардовым тканям небольшой процент хлопка или льна, входящих в структуру в сочетании с полиэстром, вискозой или полиамидом. Но самым распространенным сырьем для этой группы тканей является ацетат.

Бархат - удивительная ткань с приятным туше и волнующим мерцанием, то ярким, то едва различимым и таинственным, при этом он поражает разнообразием приемов декорирования: вытравной, вышитый, стеганый, мятый, инкрустированный, шанжан. 
Современное семейство бархата велико, однако и по сей день основу его составляют следующие структуры. Шифон-бархат - легкий, мягкий полубархат на тканой основе; бархат-деворё - легкий, мягкий драпирующийся бархат с просвечивающимся рисунком, сделанным из натурального шелка в основе и искусственного в ворсе. Его называют еще бархат с выжигом или пан-бархат (отечественная терминология); бархатперламутр - бархат из натурального неокрашенного шелка в основе и с ворсом, отличающимися по цвету, что дает изменчивое жемчужное мерцание; лионский бархат - жесткий толстый бархат на основе из натурального шелка, хлопка, искусственного шелка или полностью из синтетики; баги-р a - плотный бархат с грубоватой поверхностью, которая делает его особо прочным. Используется для платьев и вечерних накидок. Более тяжелый бархат часто называют бархат-велюр. Бархаты платьевые, велюры отличаются красивым благородным внешним видом с переливающимися оттенками цвета при движении и создании драпировок в изделии. Они используются в изготовлении платьев, платьев-костюмов, юбок и других видов женской нарядной одежды.

\section{Синтетические (Искусственные) ткани}

Синтетические ткани получают путем химической переработки газа, нефти и химических соединений. К синтетическим тканям относят различные виды полиэстера, полиамид, полипропелен, акрил, эластан. Такие ткани были изобретены с целью экономии. Поэтому вещи из синтетического материала более дешевые и менее приятные в носке. Хотя, как показывает практика, есть люди более требовательные к ощущениям на теле и люди, которым в синтетике вполне комфортно, главное то, как вещь выглядит.

Существуют еще так называемые искусственные ткани, которые получаются из природных материалов органического происхождения (целлюлоза, белки, металл) - вискоза, ацетат, рэйон, ткани с люрексом. Искусственные ткани менее вредны и более приятны наощупь.

Триацетат - недорогая искусственная материя на основе целлюлозы. Внешне похожа на шёлк, но в ней присутствуют все свойства химических материалов. Имеет неплохие потребительские свойства и в сочетании с невысокой стоимостью популярна. Состав материала - отходы хлопковой или древесной целлюлозы. Их ацетилируют полностью или частично. И-за этого она считается безопасной для окружающей среды. Ткань по описанию схожа с натуральным шёлком. Блестит и переливается, приятна на ощупь. Лучше 
шёлка держит складки и плиссировку. По внешнему виду их не различить. Гладкая, легко скользит.

Лавсан (полиэтилентерефталат) - синтетический материал, разработанный в пятидесятых годах прошлого века в нашей стране. В настоящее время лавсан широко применяется в разных областях и сферах деятельности благодаря своим исключительным качествам. Термин лавсан применительно к полиэтилентерефталату распространен в России, в других странах этот материал называется иначе - в США это дакрон, в Японии теторон, в Германии - текадур, в Великобритании - терилен, и т.д.

Сырьем для полиэтилентерефталата является нефть. По сути конечный продукт - линейный жесткоцепный полимер. Благодаря усиленным межмолекулярным воздействиям полимер обладает очень высокой прочностью. В процессе производства гранулы полиэфира расплавляются при температуре 260 градусов С и на следующем этапе из расплава путем вытягивания образуют волокна, из которых затем ткут полотно. В лавсане не заводятся пылевые клещи и плесень, это неблагоприятная среда для микроорганизмов. Водопоглощение лавсановых волокон крайне низкое, т.е. ткань не намокает, вода с нее просто скатывается. Материал устойчив к механическим повреждениям, а также к действию химических веществ (устойчив к кислотным и слабощелочным средам) и высоких (до 170 градусов С) температур.

Органза - Она может быть матовой и блестящей, изменчивой в цвете и сияющей радужными переливами, украшенной тонкой вышивкой или изящной перфорацией. Но как бы ни выглядел этот материал, он всегда несёт в себе радость праздника и доброй сказки. Первоначально органза изготавливалась из шёлковых нитей, каждая из которых получалась крепким скручиванием отборных, прозрачных, не имеющих дефектов волокон. Прозрачный, жестковатый, шелковый материал был крайне дорогой, его покупали только самые знатные модницы Европы. В дальнейшем, с появлением вискозы и синтетических материалов ткань получила множество новых образов и стала более доступной по стоимости. Состав современной органзы - это, в основном, 100\% полиэстер. Высокие технологии обработки позволили делать прозрачные нити гранёными.

Полиамидные ткани - это синтетический материал, который получается в процессе переработки органических природных ресурсов. Нефть, газ или каменный уголь сначала преобразуются в полимер. Потом из него 
формируются полиамидные волокна и нити. На завершающем этапе нити превращаются в ткани, обладающие удивительными свойствами.

У синтетических волокон - великолепные функциональные характеристики. Ткани из них отличаются многообразием и лёгкостью. Они могут быть блестящими, гладкими, матовыми или шероховатыми. В промышленности принято официальное название этих тканей - РА. Единственное, чем отличаются полиамидные ткани, состав: наиболее известный капрон - это РА 6, нейлон полиамид - это РА 6,6, РА 12 и т.п. Из полиамидных волокон делают ленты для транспортёров, рыбацкие сети, прочные канаты и кордовые ткани для производства шин. Также, из полиамидных тканей изготавливают износостойкое и приятное к телу нижнее бельё, синтетические волокна добавляют эффектности и прочности колготкам. Эластичность и способность сохранять форму нашли применение материалу в производстве высококачественных мужских носков.

Акриловые нити получаются очень прочные и непрерывные. Это позволит создавать удивительно равномерное переплетение, а также дает возможность полной имитации вязки шерстяных мотивов. Это свойство широко используется при создании теплых вещей, ведь даже на ощупь такое полотно сложно отличить от натурального аналога.

Вискоза состоит из целлюлозы, которая представляет собой волокнистый химикат, обнаруженный во всех растениях. Кора дерева, а также жесткие части сельдерея, сделаны из целлюлозы. Некоторые виды вискозы изготавливаются из хлопкового пуха, коротких хлопковых волокон, оставшихся на семенах хлопчатника после измельчения.

Полиэстер (polyester, ПЭ) самая распространенная синтетическая ткань. На постельном и нижнем белье, одежде, нередко можно увидеть такое сочетание букв «polyester». Но не только ткани, но и пластиковые контейнеры, бейджи и пакеты изготавливаются благодаря такому химическому сочетанию. Такое разнообразие сфер применения объясняется тем, что при температуре выше 40 градусов полиэстер сохраняет заданную форму. В производстве одежды это качество также является плюсом, так как все складки, зажимы и первоначальная форма изделия даже при многочисленных стирках останется неизменной. Полиэстер получается в результате многоуровневой химической реакции мономеров. Он изготавливается из соединений, содержащихся в нефти. К ним относится этиленгликоль и терефталевая кислота. На ощупь изделия из полиэстера похожи на разные ткани. Это может быть хлопок, 
шерсть и даже шелк. 100 процентный полиэстер (polyester, ПЭ), кстати, так и называют «декоративный шелк». Что это за ткань получится, зависит от способа выработки и наличия дополнительных волокон в составе ткани.

Барби - износостойкий, мягкий, не нуждающийся в глажке материал, приятно прилегающий к телу и обеспечивающий ему комфорт благодаря своим свойствам. Из нее производятся деловая одежда: костюмы, пиджаки, юбки, брюки, комбинезоны, а также школьная форма.

Эта ткань является достаточно гигроскопичной. Состав ее преимущественно натуральный, но также в ней присутствует эластин, являющийся синтетической добавкой. Он улучшает физические свойства ткани, делая ее более облегающей и удобной. Поверхность ткани шероховатая, приятная на ощупь. Но при этом ткань эластичная, хорошо тянется и облегает фигуру. Материал имеет свойство пропускать через себя воздух и вентилировать тепло с водой, что поддерживает комфорт и не позволяет вспотеть. Если же одежда зимняя, то эта ткань, напротив, хорошо сохраняет тепло и не дает замерзнуть. Отличие этого материала от обычного костюмного крепа не только в гладкой поверхности. Материя прекрасно тянется, причем как по утку, так и по основе.

Материал состоит из синтетических волокон, в основном, из полиэстера и спандекса. Последний может быть заменен на эластан. Наличие в составе только синтетического волокна говорит об устойчивости к любого вида деформации, но, в добавок к этому, о низкой гигроскопичности и воздухопроницаемости.

\section{Состав и свойства необычных и популярных тканей}

Среди текстиля есть материи, созданные для особого применения. Они предназначены для того, чтобы защитить человека в самых экстремальных ситуациях на самой опасной работе. Астронавтов и пилотов, танкистов и пожарных, полицейских и сотрудников МЧС от огня и высоких температур спасает одежда, основу которой составляет особая Арамидная ткань. Слово «арамид» возникло от сокращения названия «ароматический полиамид». Эту синтетическую ткань впервые получили американские химики компании DuPont в середине прошлого столетия.

Вскоре были созданы и другие защитные ткани - тварон, номекс, кермель. Беларусь начала производить уникальный материал арселон, отечественные химики изобрели превосходящий зарубежные аналоги по ряду характеристик русар, который иногда называют арусом. Среди отечественных 
специальных волокон из класса арамидных можно отметить: волокно СВМ, Терлон, Армос.

Арамидное волокно жёлтое, блестящее имеет особую структуру. Их переплетают разными способами: полотняным, саржевым, атласным, вафельным. Сложное строение волокон определяет уникальные качества тканей. Высочайшая прочность, значительно превосходящая нейлон и не уступающая стальным изделиям. Материал разрывается при приложении гигантских усилий: от 250 до 600 кг на квадратный миллиметр. Лёгкость. Материал имеет плотность 1400-1500 кг/м куб, оно почти в 2 раза легче стекловолокна. Высочайшее сопротивление механическим воздействиям. Ткань способна противостоять пулевым ударам. Непревзойдённая термостойкость. Арамидные ткани не теряют своих качеств при температуре до $250-400^{\circ} \mathrm{C}$. Они выдерживают кратковременный тепловой удар в $1000^{\circ} \mathrm{C}$. Абсолютная биоустойчивость. Материалу не страшны не грибки, ни бактерии, поэтому он не гниёт и не впитывает неприятные запахи. Стабильность размеров. Арамидная ткань сохраняют форму на протяжении всего срока эксплуатации.

Арамиды в виде тканей или волокон используются в самолёто- и ракетостроении. Они находят широкое применение в народном хозяйстве. Из сверхпрочного материала получаются отличные ленты для транспортёров, арматура для автошин и крепкие тросы, а также арамидную бумагу. Из него также делают безупречные оптико-волоконные кабели. Инновационные арамидные ткани уже более полувека стоят на страже жизни и здоровья человека. Они сокращают рабочие риски и даже обеспечивают комфорт представителям самых опасных, огненных профессий.

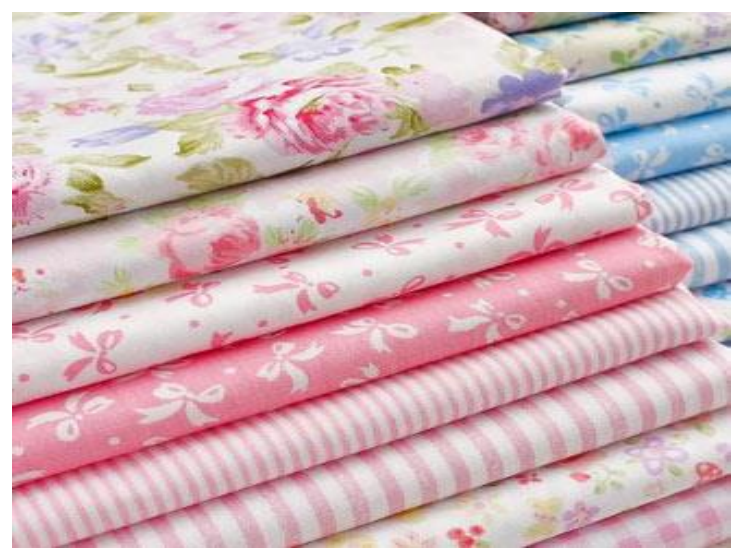

Хлопчатобумажный ситеи

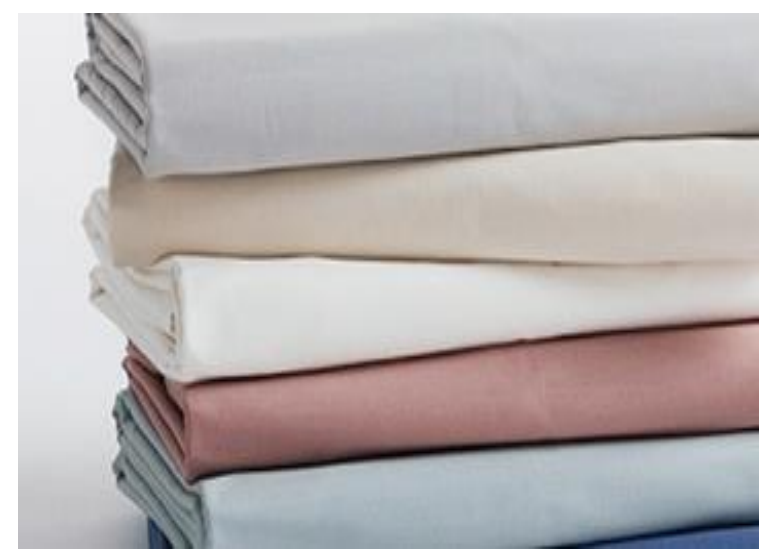

Хлопчатобумажный бязь 


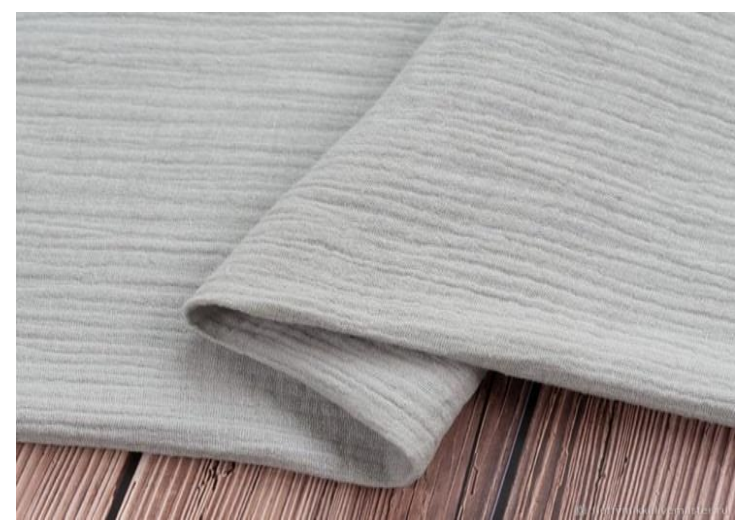

Шёлковый Муслин

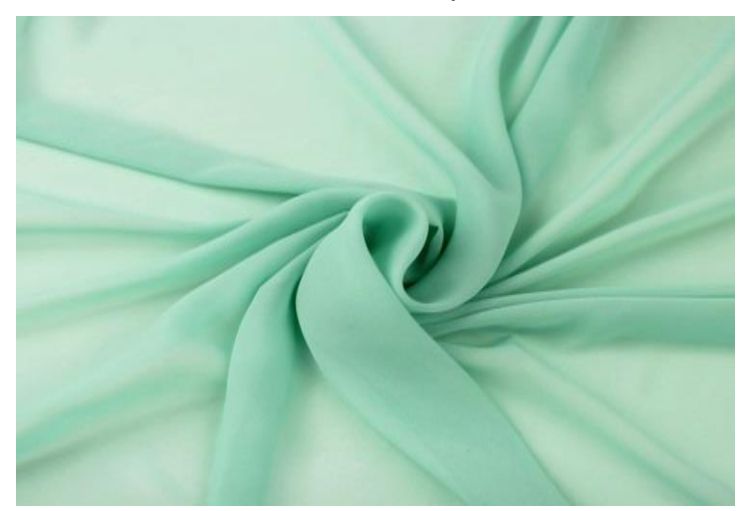

Шифон из хлопковых тонких нитей с добавлением других нитей

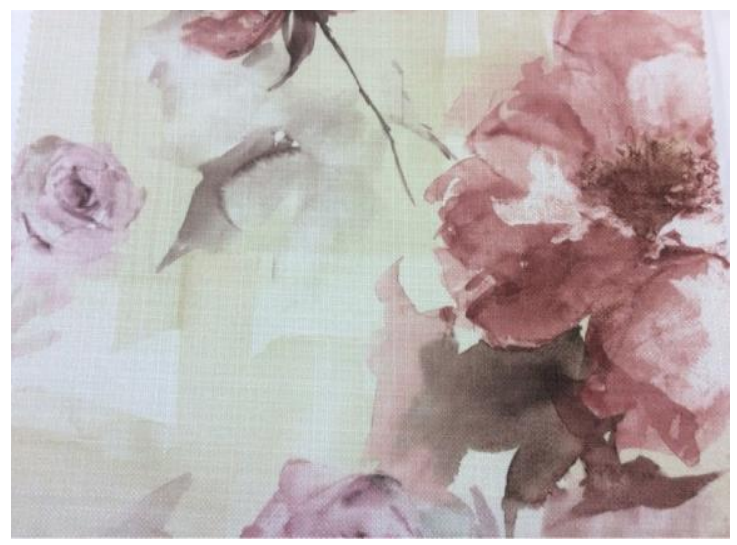

Лён «Акварель»

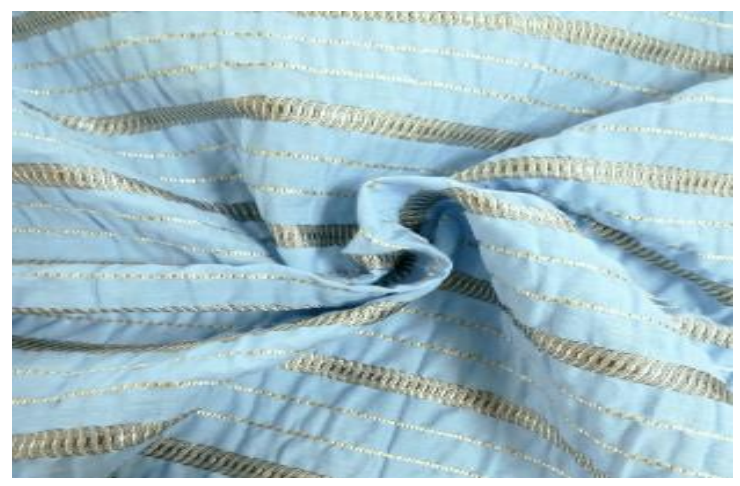

Хлопок Тафта

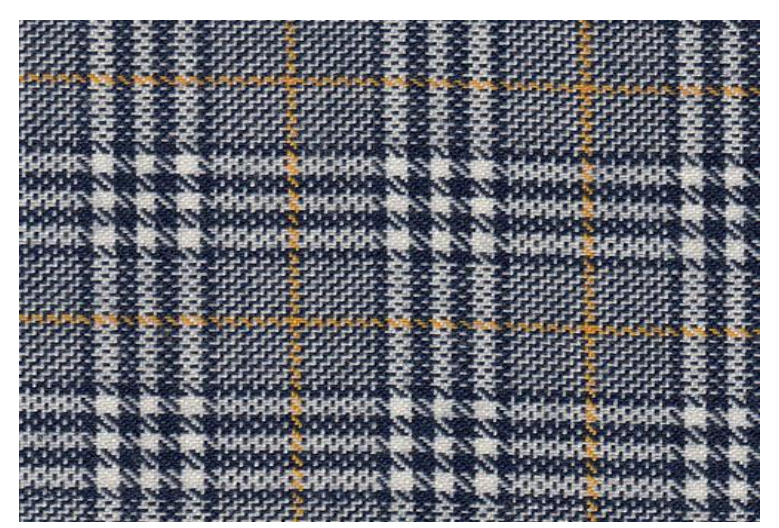

Хлопчатобумажный Гринсбон

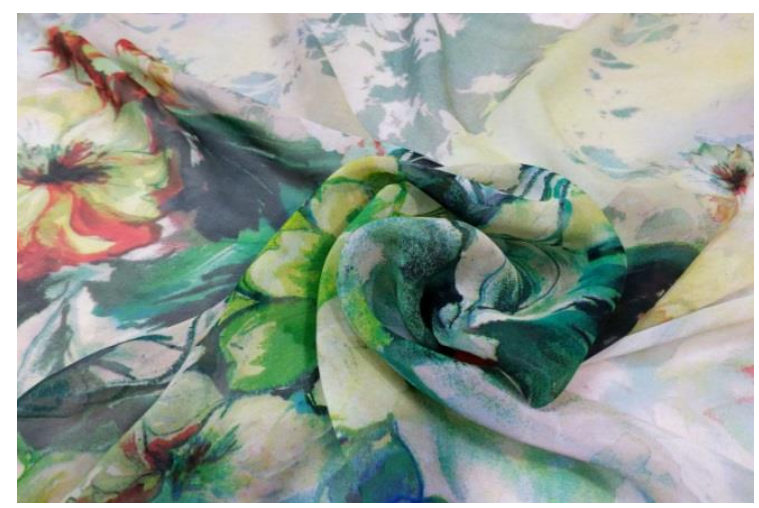

Шёлковый шифон

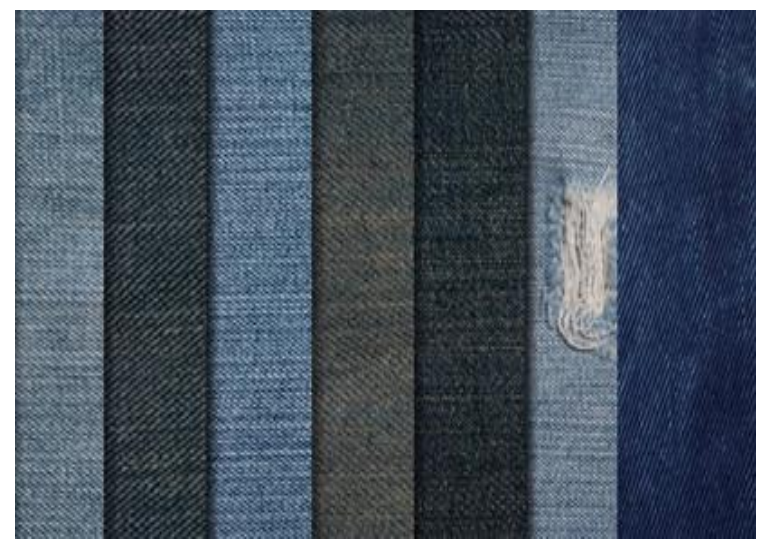

Деним (Джинсовая ткань)

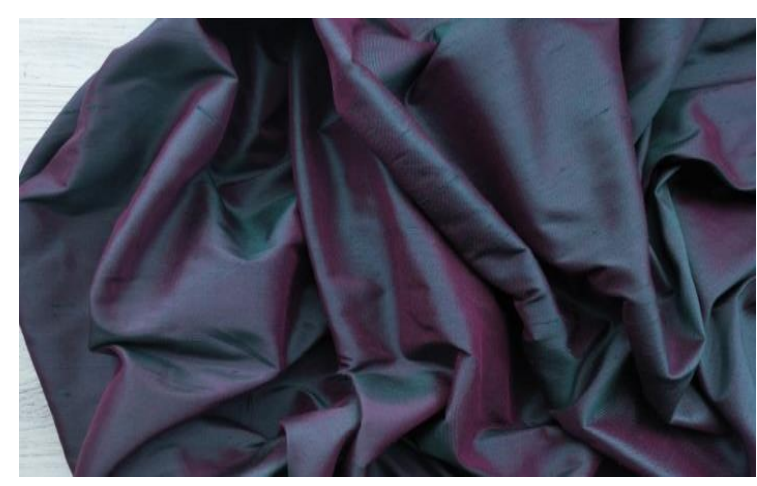

Тафта шёлк 100\% 


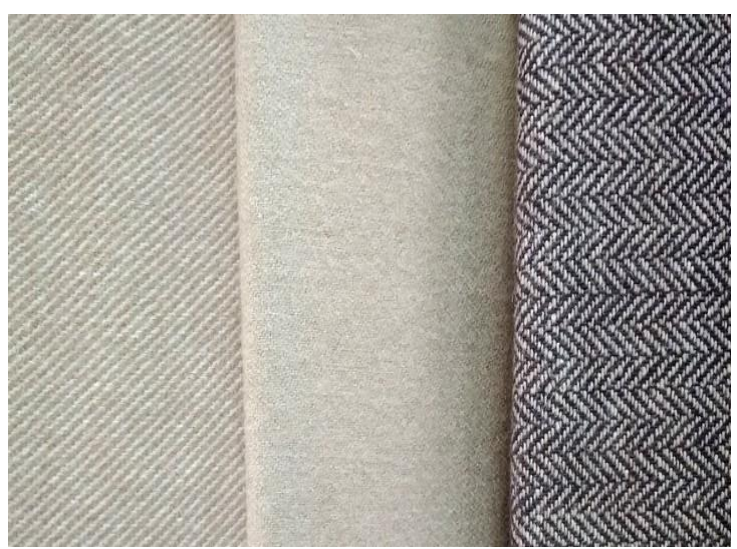

Шерстенной Твид

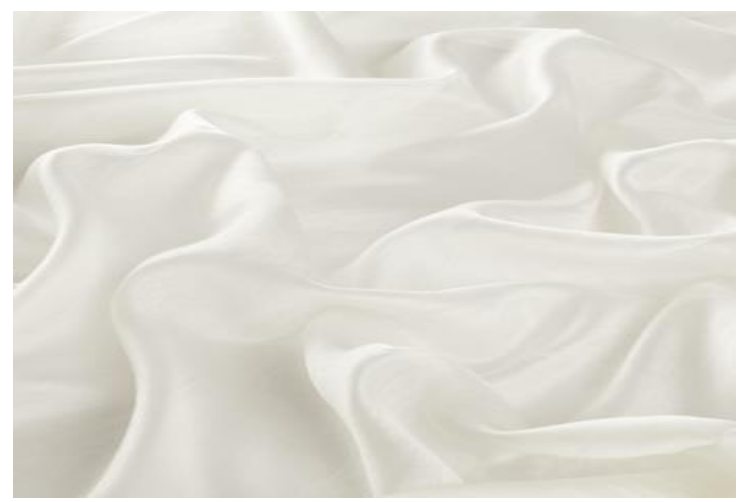

Шёлковый Вуаль

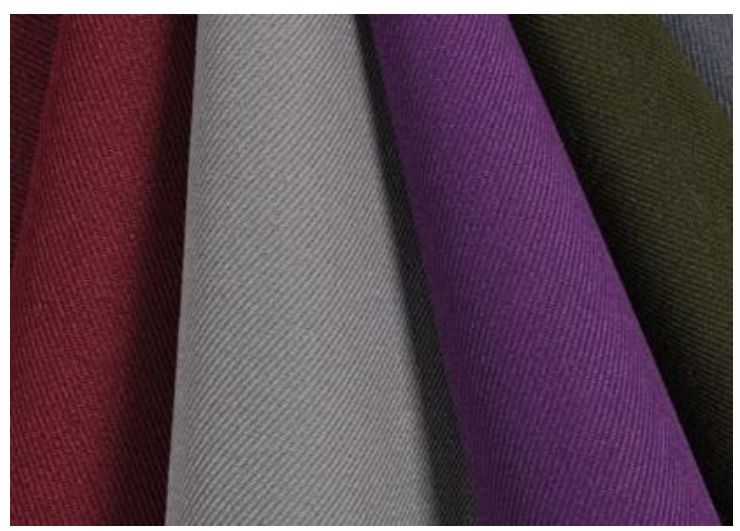

Шерстяной Габардин

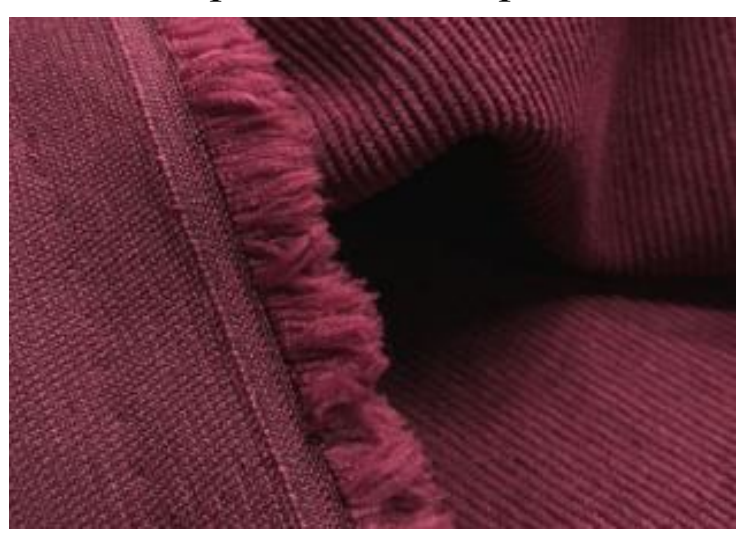

Вельвет

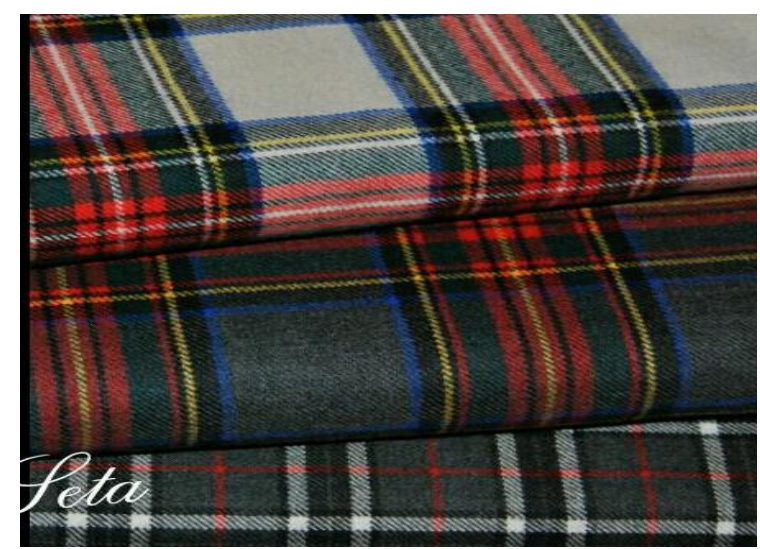

Шотландка

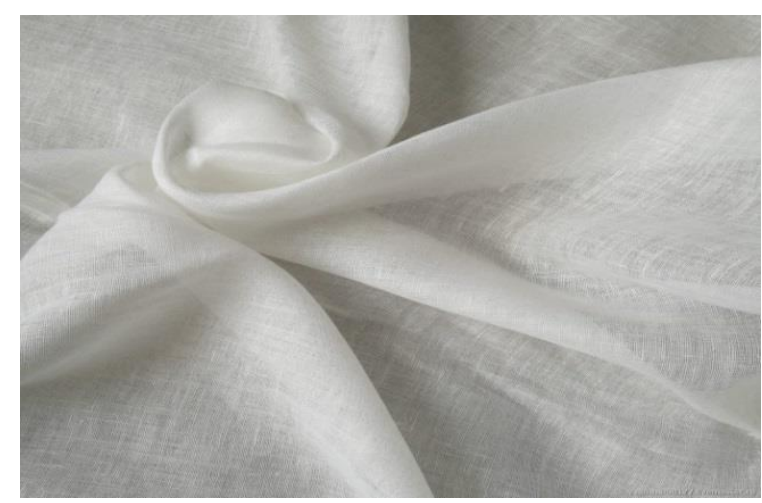

Лён-вуаль

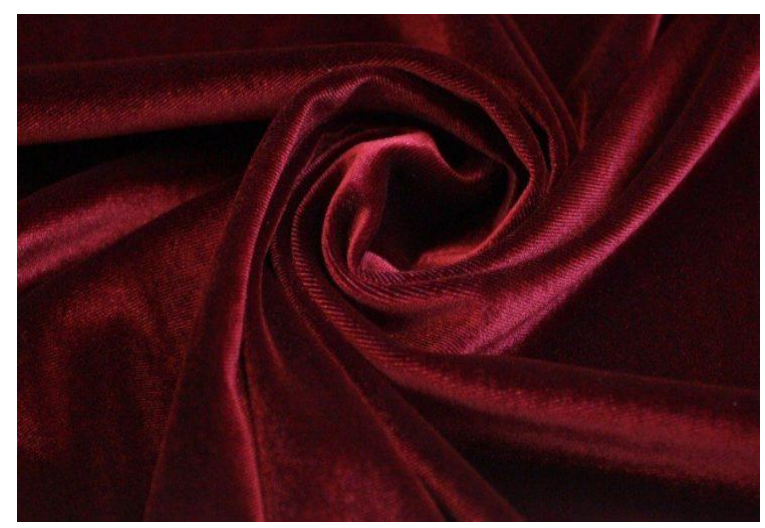

Бapxam

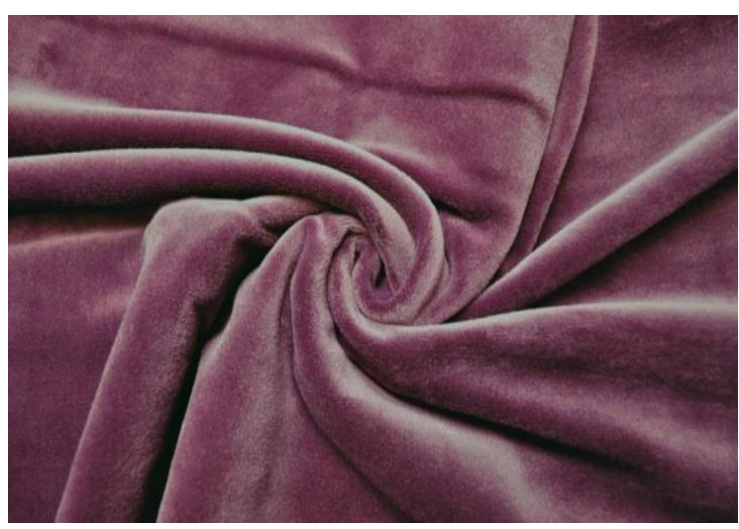

Велюр 


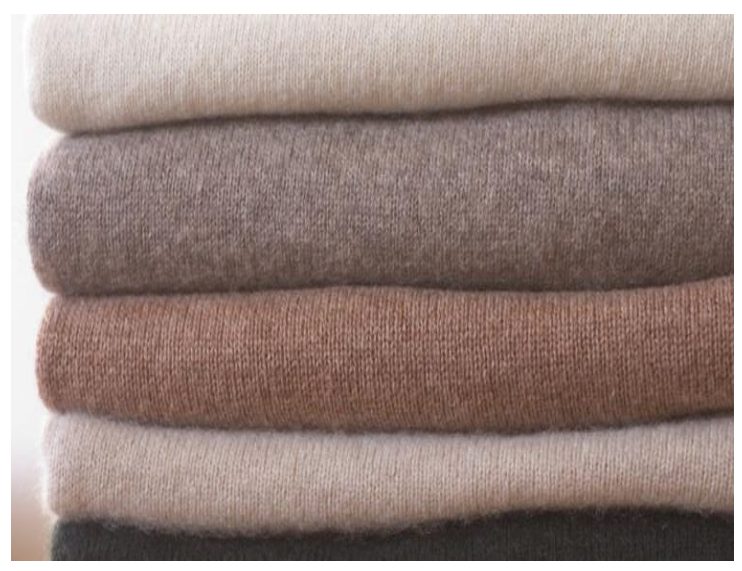

Камемир (шерсть)

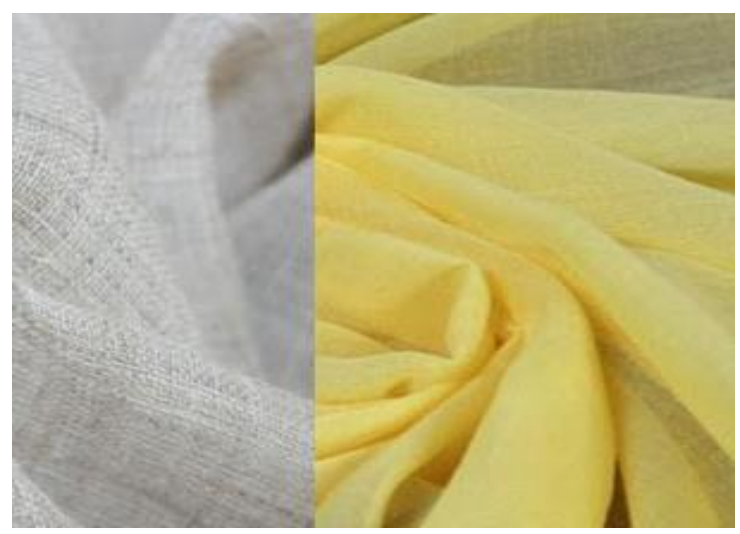

Маркизет хлопчатобумажная

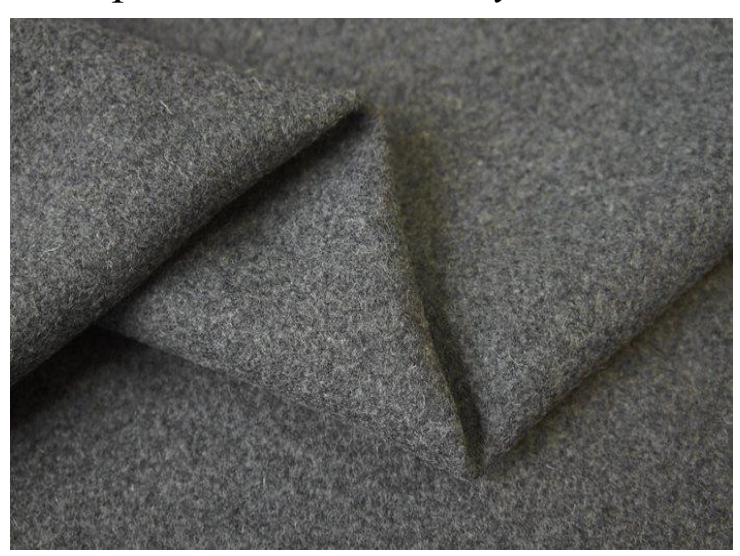

Сукно

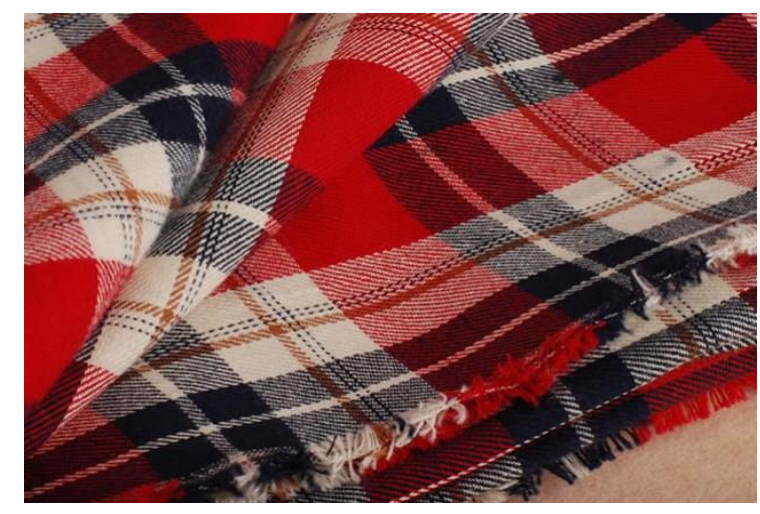

Фуле
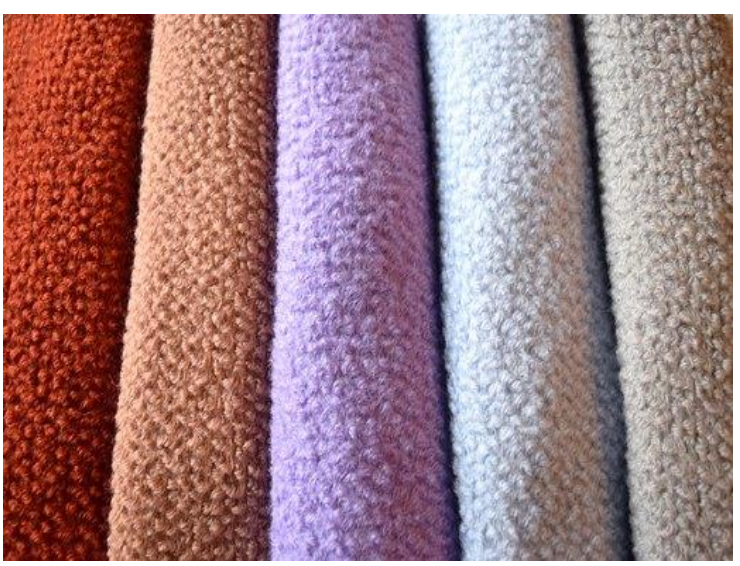

Букле

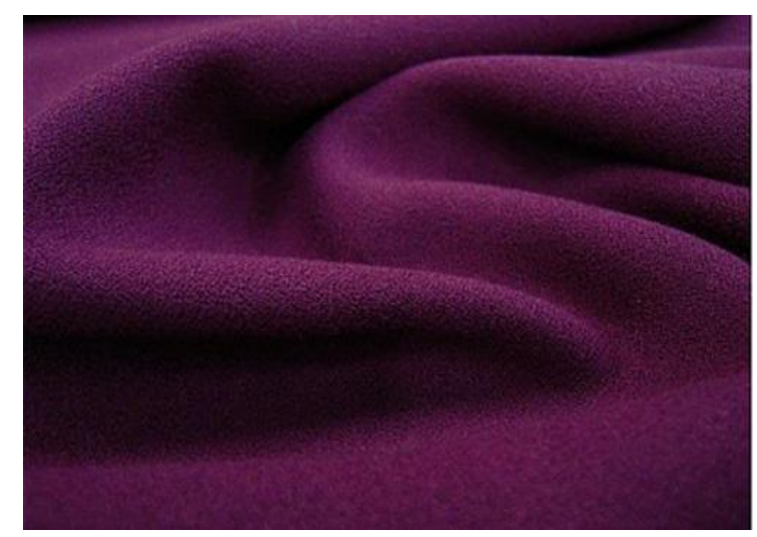

Шевиот

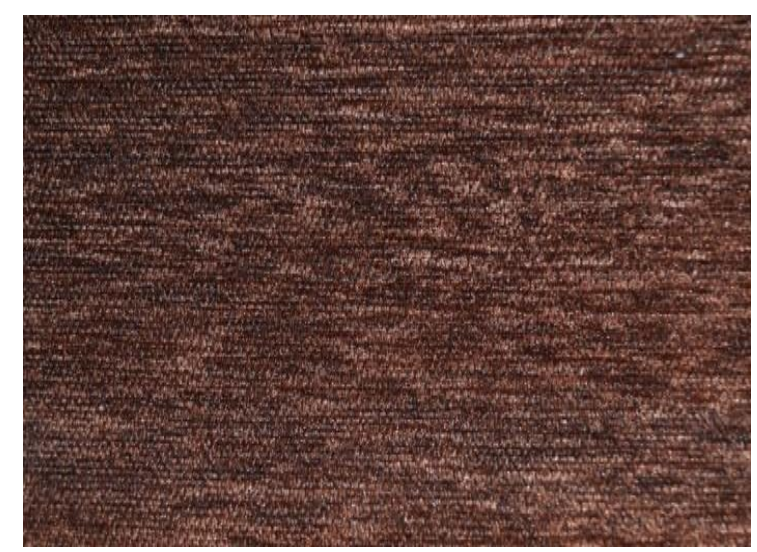

Мебельная ткань Бостон

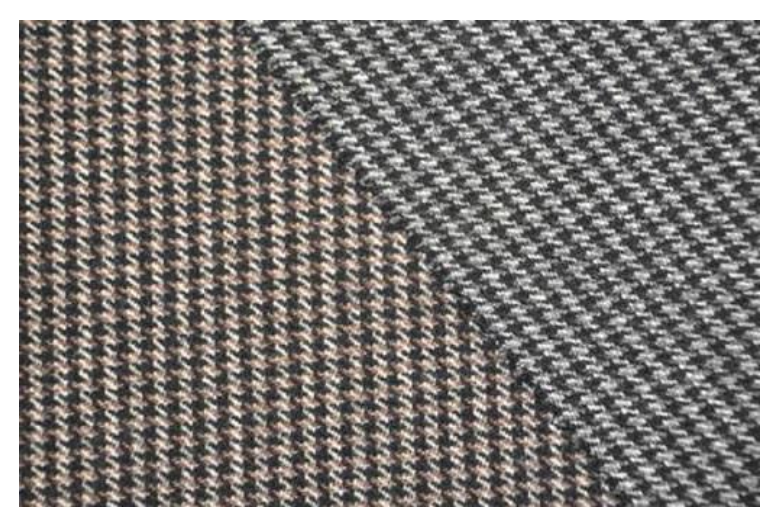

Коверкот 

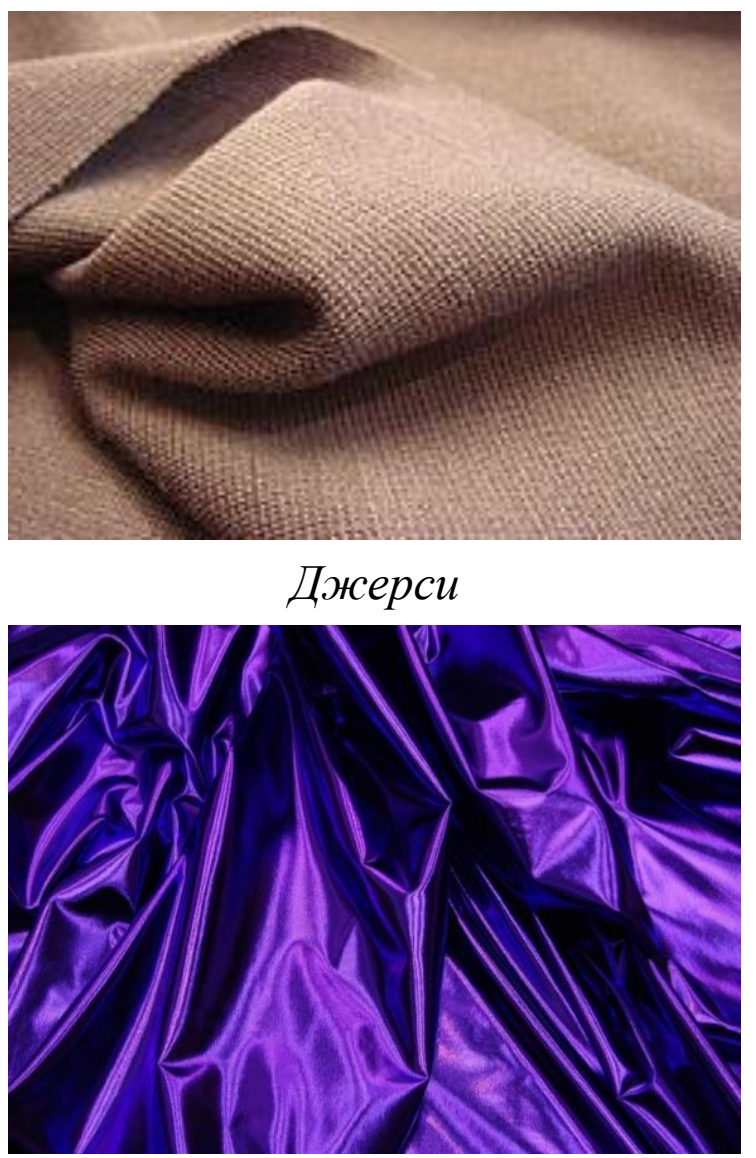

Лайкра

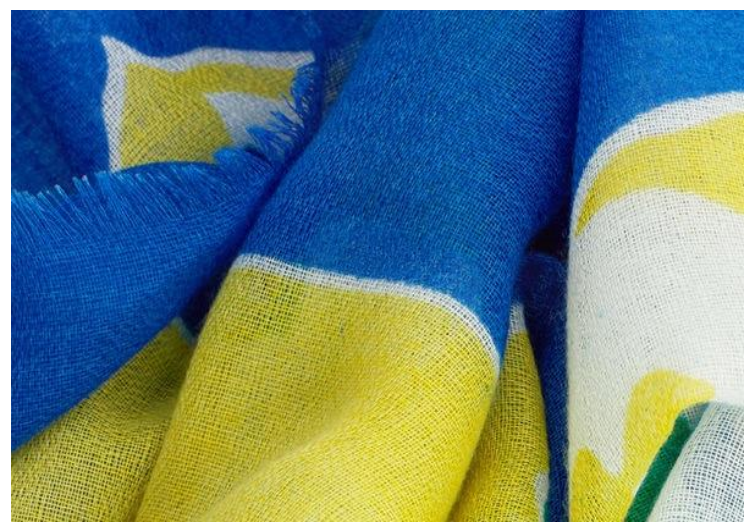

Фуляр

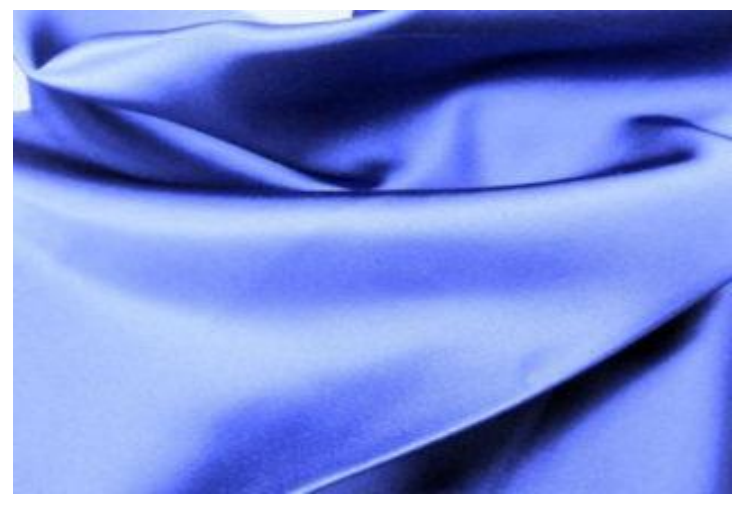

Tpuauemam

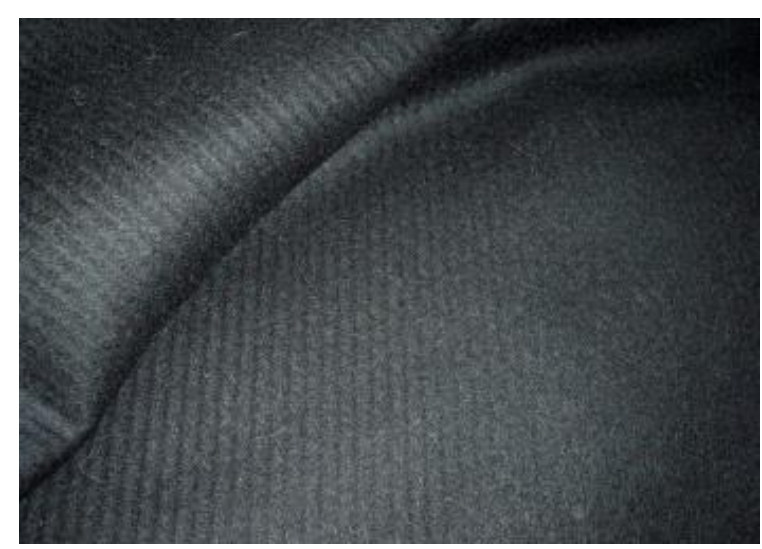

Трико

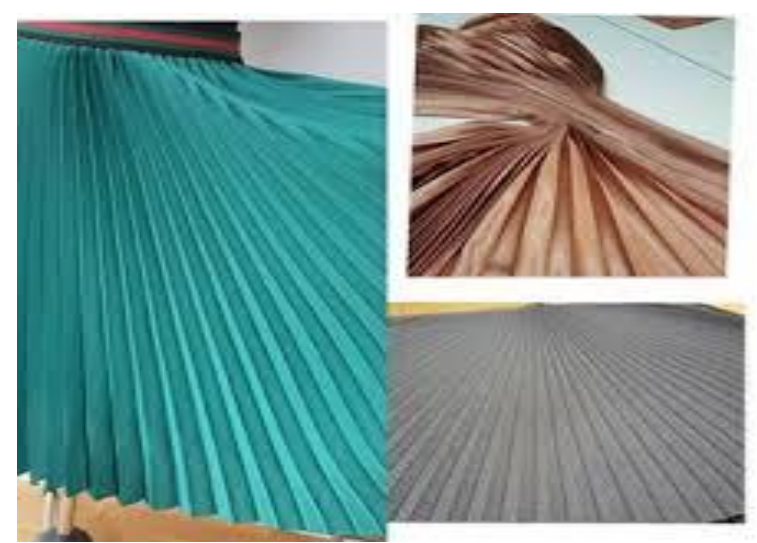

Kpen-гофpe

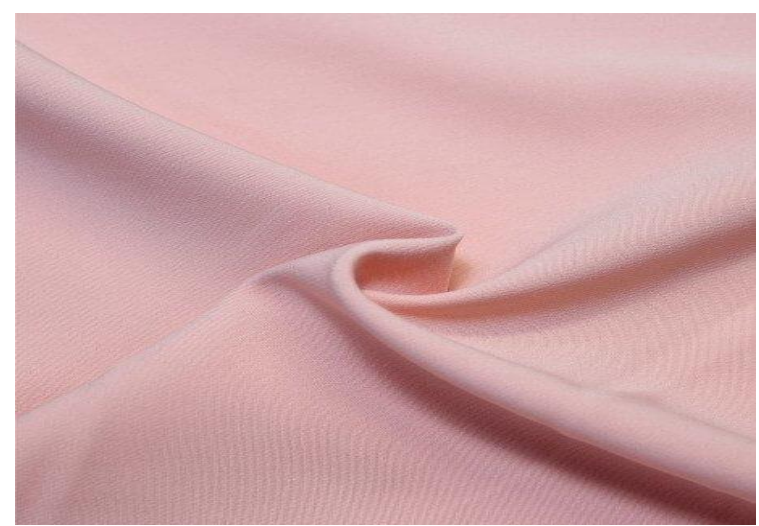

Барби

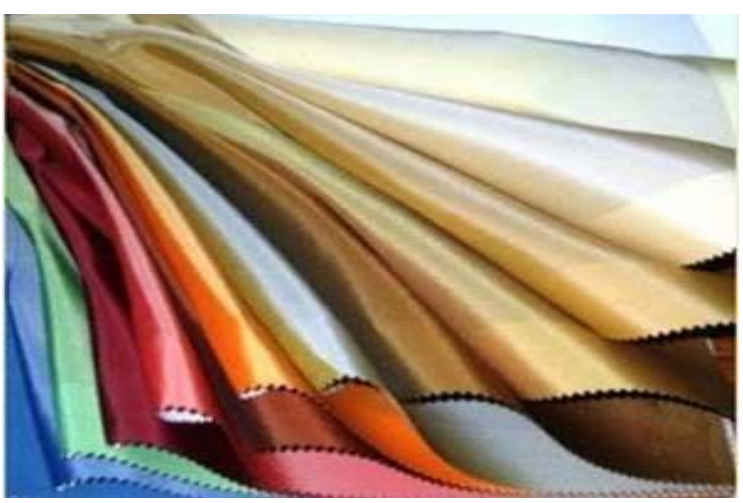

Лавсан 

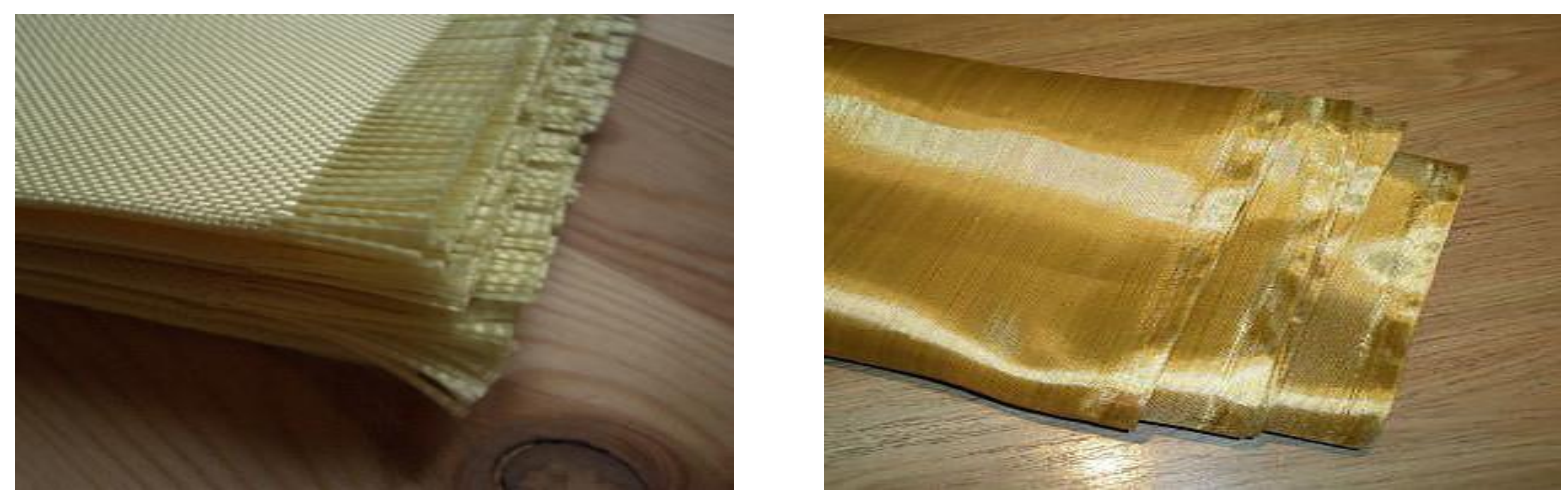

\section{Арамиды}

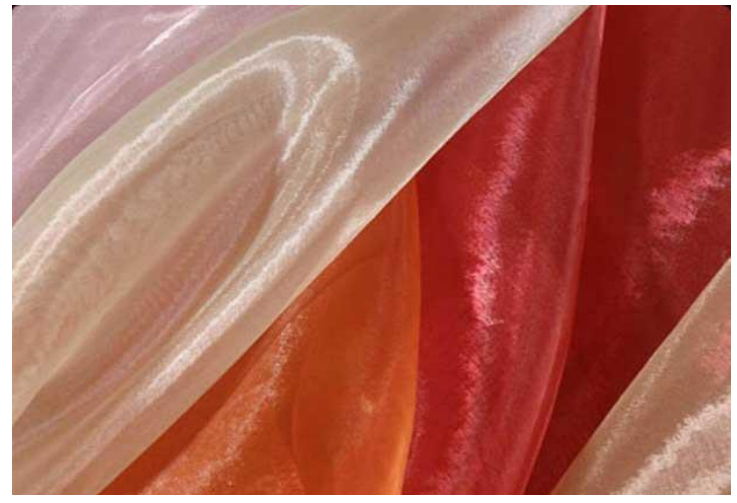

Органза

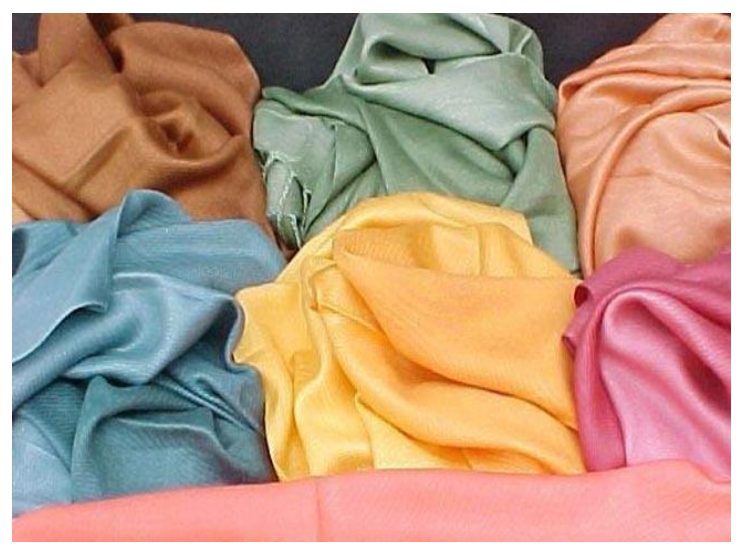

Вискоза

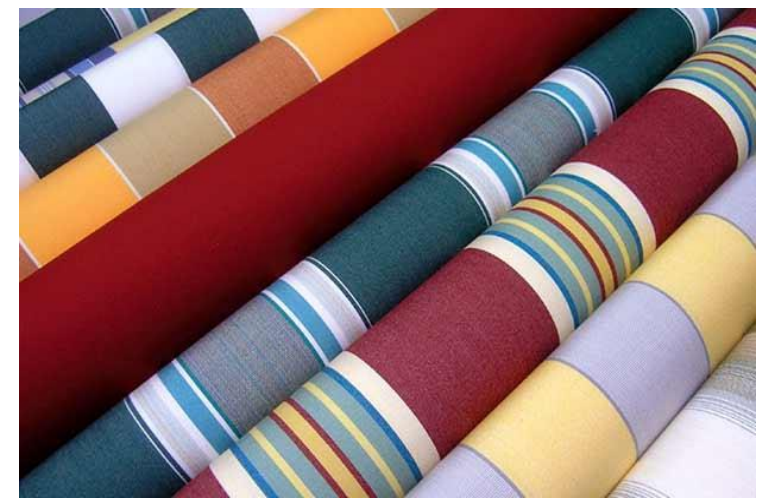

Акрил

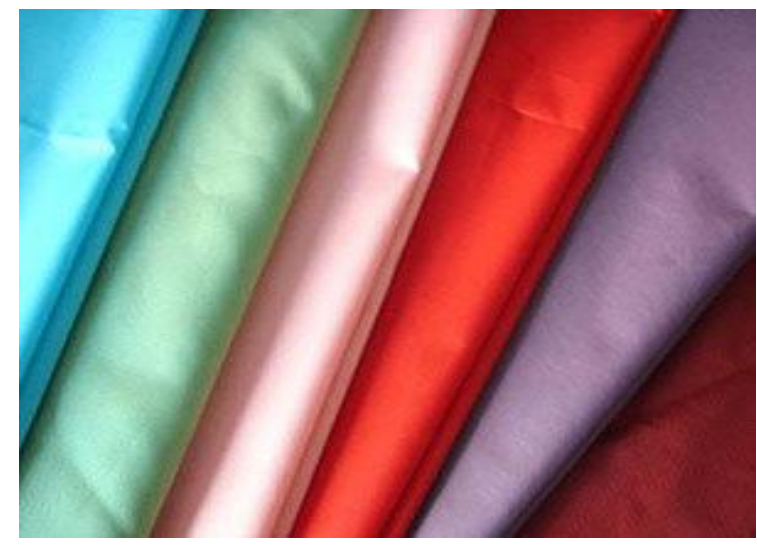

Полиэстер

(C) 3.А. Яминзода, 2021 